Studies by the U.S. Geological Survey in Alaska, 2008-2009

\title{
Location and Extent of Tertiary Structures in Cook Inlet Basin, Alaska, and Mantle Dynamics that Focus Deformation and Subsidence
}

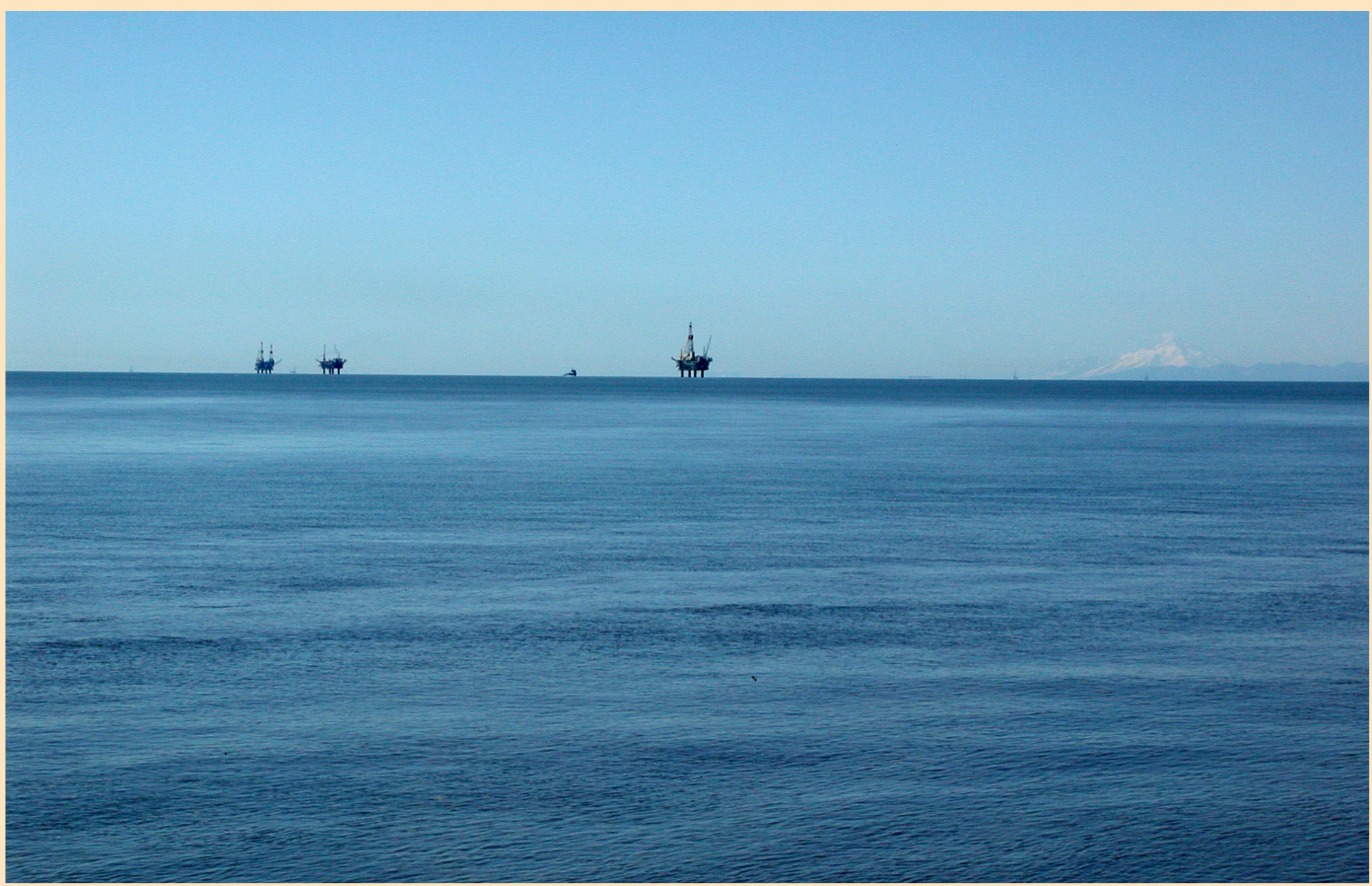

Professional Paper $1776-D$

U.S. Department of the Interior U.S. Geological Survey 


\section{Front Cover}

Oil platforms in Cook Inlet mark the crest of subsurface anticlines. This view is from Granite Point looking to the southwest down Cook Inlet. Illiamna Volcano lies in the far distance on the right. 
Studies by the U.S. Geological Survey in Alaska, 2008-2009

\section{Location and Extent of Tertiary Structures in Cook Inlet Basin, Alaska, and Mantle Dynamics that Focus Deformation and Subsidence}

By Peter J. Haeussler and Richard W. Saltus

Professional Paper 1776-D 


\section{U.S. Department of the Interior KEN SALAZAR, Secretary}

\section{U.S. Geological Survey Marcia K. McNutt, Director}

\section{U.S. Geological Survey, Reston, Virginia: 2011}

This report and any updates to it are available online at:

http://pubs.usgs.gov/pp/1776/d

For more information on the USGS - the Federal source for science about the Earth, its natural and living resources, natural hazards, and the environment:

World Wide Web: http://www.usgs.gov/

Telephone: 1-888-ASK-USGS

Any use of trade, product, or firm names in this publication is for descriptive purposes only and does not imply endorsement by the U.S. Government.

Although this report is in the public domain, it may contain copyrighted materials that are noted in the text. Permission to reproduce those items must be secured from the individual copyright owners.

Library of Congress Cataloging-in-Publication Data

Suggested citation:

Haeussler, P.J., and Saltus, R.W., 2011, Location and extent of Tertiary structures in Cook Inlet Basin, Alaska, and mantle dynamics that focus deformation and subsidence, in Dumoulin, J.A., and Galloway, J.P., eds., Studies by the U.S. Geological Survey in Alaska 2008-2009: U.S. Geological Survey Professional Paper 1776-D, 26 p. 


\section{Contents}

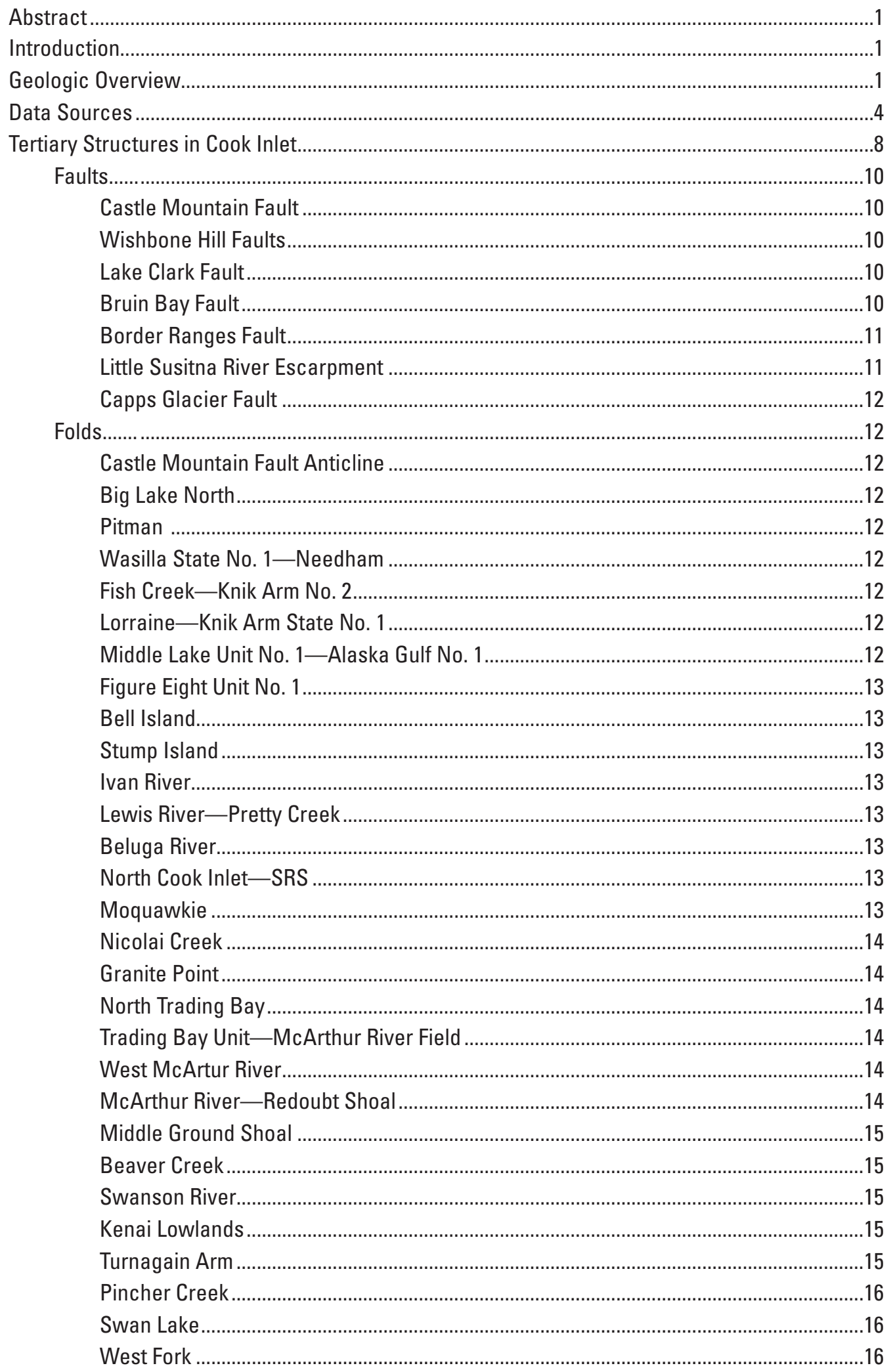




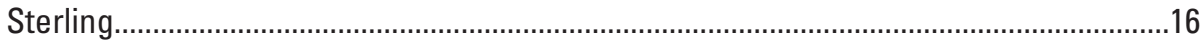

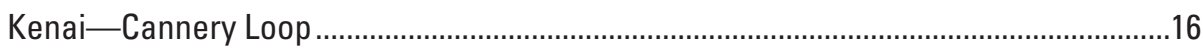

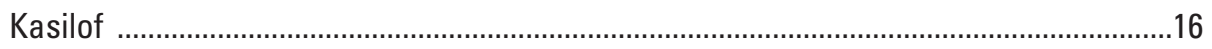

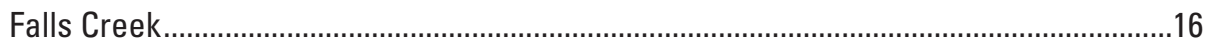

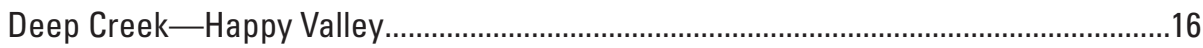

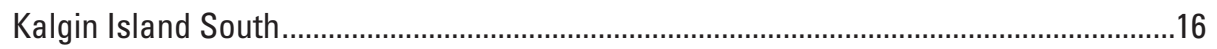

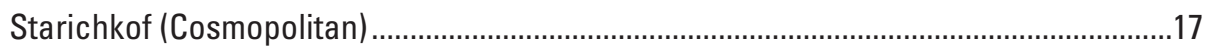

North Fork—Nikolaevsk .....................................................................................17

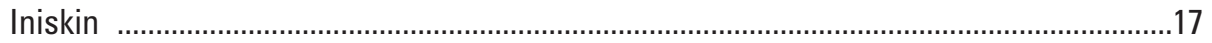

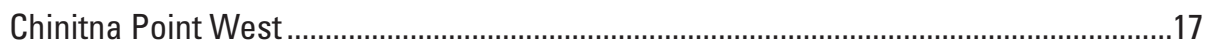

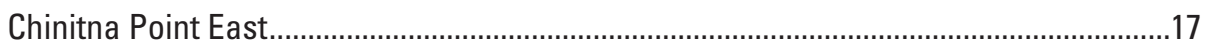

Hawk

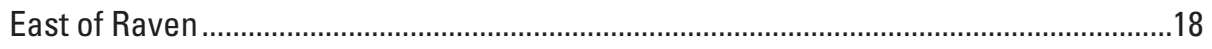

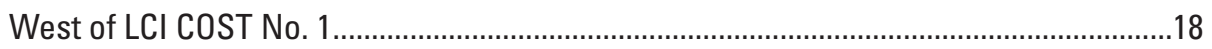

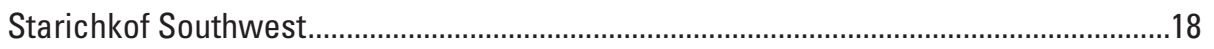

Kachemak

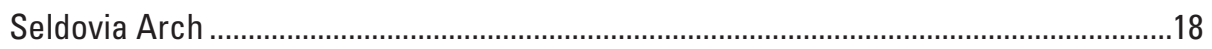

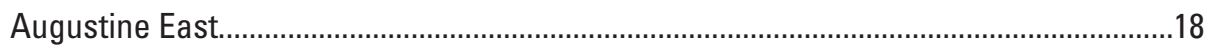

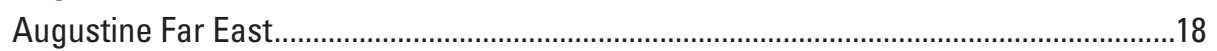

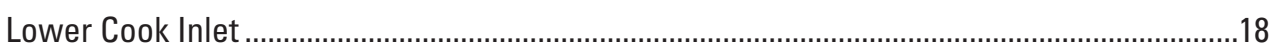

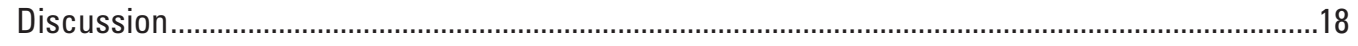

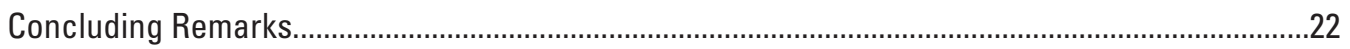

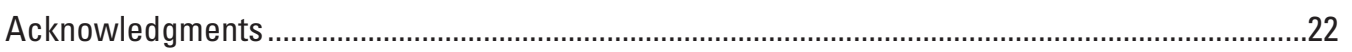

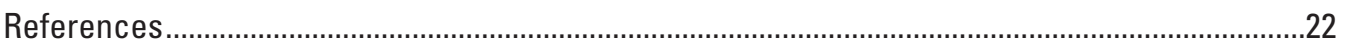

\section{Figures}

1. A, Location of Tertiary anticlines and faults in Cook Inlet Basin, Alaska; $B$, Seismic-reflection profiles used for the interpretations in this report........................2

2. Three views of the stratigraphic column for Tertiary Cook Inlet Basin sediments..........5

3. Magnetic maps of the Cook Inlet region, with faults and folds shown as on figure $1 A$, listed in table 1 , and discussed in the text......................................................

4. Detailed two-dimensional magnetic model along part of seismic line 285-1, Cook Inlet Basin, Alaska 6

5. Maps showing the relationship of the Cook Inlet Basin to the subducted Yakutatterrane slab, Alaska .......................................................................................20

6. Map showing Yakutat slab and its inferred effect on mantle fluid flow .........................21

\section{Tables}

1. Anticlines in the Cook Inlet Basin, Alaska 


\title{
Location and Extent of Tertiary Structures in Cook Inlet Basin, Alaska, and Mantle Dynamics that Focus Deformation and Subsidence
}

\author{
By Peter J. Haeussler ${ }^{1}$ and Richard W. Saltus ${ }^{2}$
}

\section{Abstract}

This report is a new compilation of the location and extent of folds and faults in Cook Inlet Basin, Alaska. Data sources are previously published maps, well locations, and seismic-reflection data. We also utilize interpretation of new aeromagnetic data and some proprietary seismic-reflection data. Some structures are remarkably well displayed on frequency-filtered aeromagnetic maps, which are a useful tool for constraining the length of some structures. Most anticlines in and around the basin have at least shows of oil or gas, and some structures are considered to be seismically active. The new map better displays the pattern of faulting and folding. Deformation is greatest in upper Cook Inlet, where structures are oriented slightly counterclockwise of the basin bounding faults. The north ends of these structures bend to the northeast, which gives a pattern consistent with right-transpressional deformation.

Subduction of the buoyant Yakutat microplate likely caused deformation to be focused preferentially in upper Cook Inlet. The upper Cook Inlet region has both the highest degree of shortening and the deepest part of the Neogene basin. This forearc region has a long-wavelength magnetic high, a large isostatic gravity low, high conductivity in the lower mantle, low p-wave velocity $\left(V_{p}\right)$, and a high p-wave to shear-wave velocity ratio $\left(V_{p} / V_{s}\right)$. These data suggest that fluids in the mantle wedge caused serpentinization of mafic rocks, which may, at least in part, contribute to the long-wavelength magnetic anomaly. This area lies adjacent to the subducting and buoyant Yakutat microplate slab. We suggest the buoyant Yakutat slab acts much like a squeegee to focus mantle-wedge fluid flow at the margins of the buoyant slab. Such lateral flow is consistent with observed shear-wave splitting directions. The additional fluid in the adjacent mantle wedge reduces the wedge viscosity and allows greater corner flow. This results in focused subsidence, deformation, and gravity anomalies in the forearc region.

${ }^{1}$ U.S. Geological Survey, 4200 University Drive, Anchorage, AK 99508. ${ }^{2}$ U.S. Geological Survey, Denver Federal Center, MS964, Denver, CO 80225 .

\section{Introduction}

The Cook Inlet basin is the longest-producing oil and gas province in Alaska. The discovery well was drilled in 1957 in the Swanson River field. All known traps of oil and gas in the basin are contraction-related features (for example, Kirschner and Lyon, 1973; Boss and others, 1976; Magoon and Claypool, 1981) and many of these are fault-cored folds (Haeussler and others, 2000; Bruhn and Haeussler, 2006). Therefore, information about the location and extent of the anticlines in Cook Inlet is critical for assessing the oil and gas resources in the region. Moreover, stratigraphic evidence indicates at least some folds are growing (Haeussler and others, 2000; Bruhn and Haeussler, 2006). Thus, knowledge of the location and extent of the structures also aids in assessing the earthquake hazard in the region. The purpose of this report is to provide an updated map of the Tertiary anticlines in the basin and the significant faults around the margins of the basin, and to try and understand the distribution of deformation in the basin.

The structural style and the tightness of the folds are variable. All folds imaged clearly on available seismicreflection data have faults associated with, or coring, the structures. However, not all of the mapped folds are oil and gas traps, as drilling data demonstrate, and not all of the mapped structures are seismically active.

\section{Geologic Overview}

Cook Inlet basin is a northeast-trending forearc basin located between the Chugach and Kenai Mountains to the southeast, and the Alaska Range and Aleutian volcanic arc to the northwest (Dickinson and Seely, 1979) (fig. 1). The subducting Pacific plate is $50-60 \mathrm{~km}$ beneath the center of the basin. Three major fault zones define the basin margins - the Castle Mountain fault on the north, the Bruin Bay fault to the northwest, and the Border Ranges fault along the southeast side (Grantz, 1966; Pavlis, 1982). Most rocks in the Chugach and Kenai Mountains are part of a vast Mesozoic and early Tertiary accretionary complex that rims the southern Alaska 


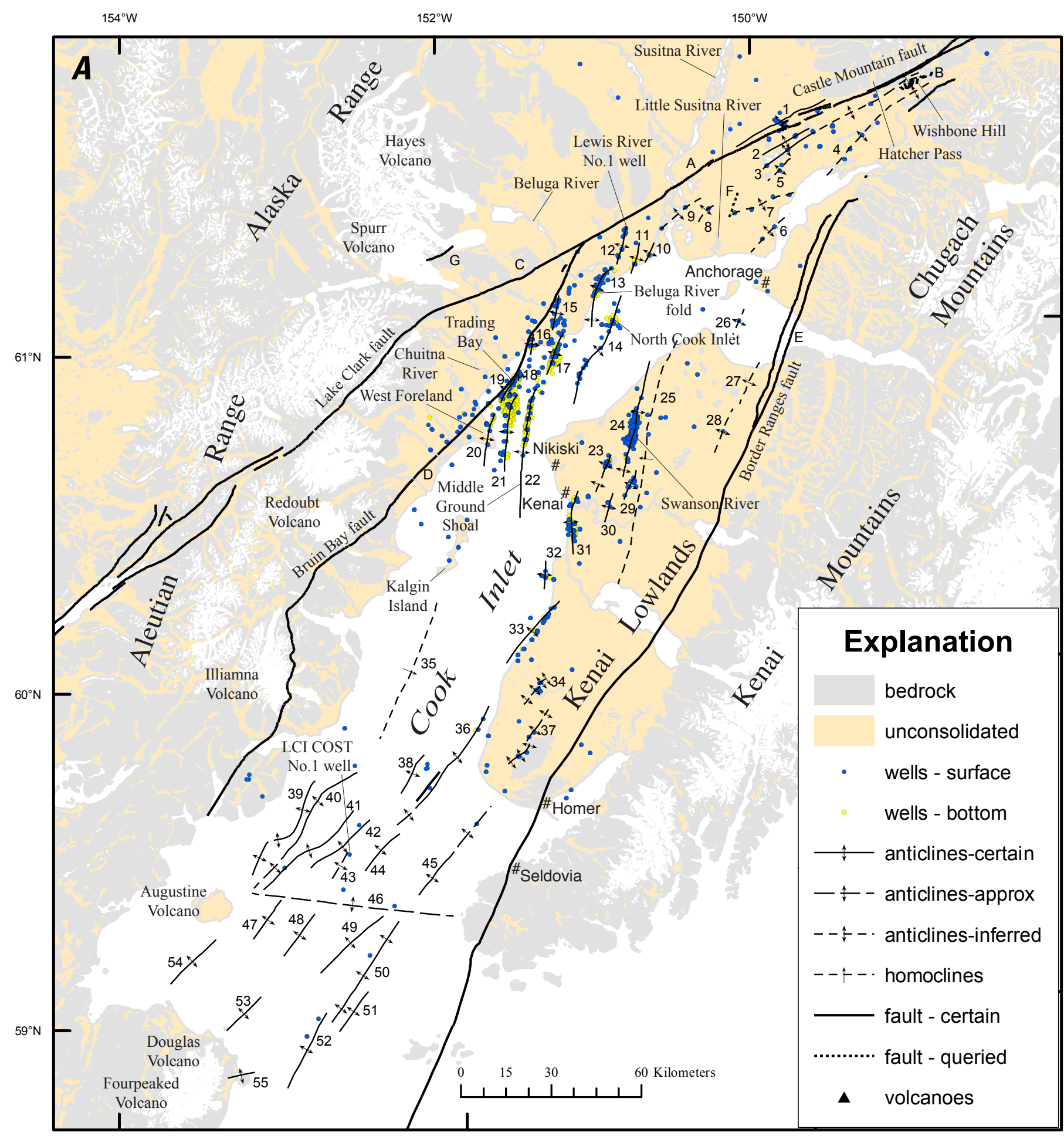

Figure 1. A, Location of Tertiary anticlines and faults in Cook Inlet Basin, Alaska. Faults are lettered and folds are numbered and refer to descriptions in the text and in table 1. Synclines are not mapped. All folds and faults are concealed by surficial deposits, but the map legend uses exposed fold symbols for greater clarity. $B$, Seismic-reflection profiles used for the interpretations in this report. Only previously published lines are labeled with their number. The data source of the profile is listed in front of the line number as follows: FM, Fisher and Magoon (1978); HBP, ARCO data published in Haeussler, Bruhn, and Pratt (2000); BH, ARCO data published in Bruhn and Haeussler (2006); NP, not published ARCO data; WG, Western Geophysical data in Fisher and others $(2008,2010)$. 


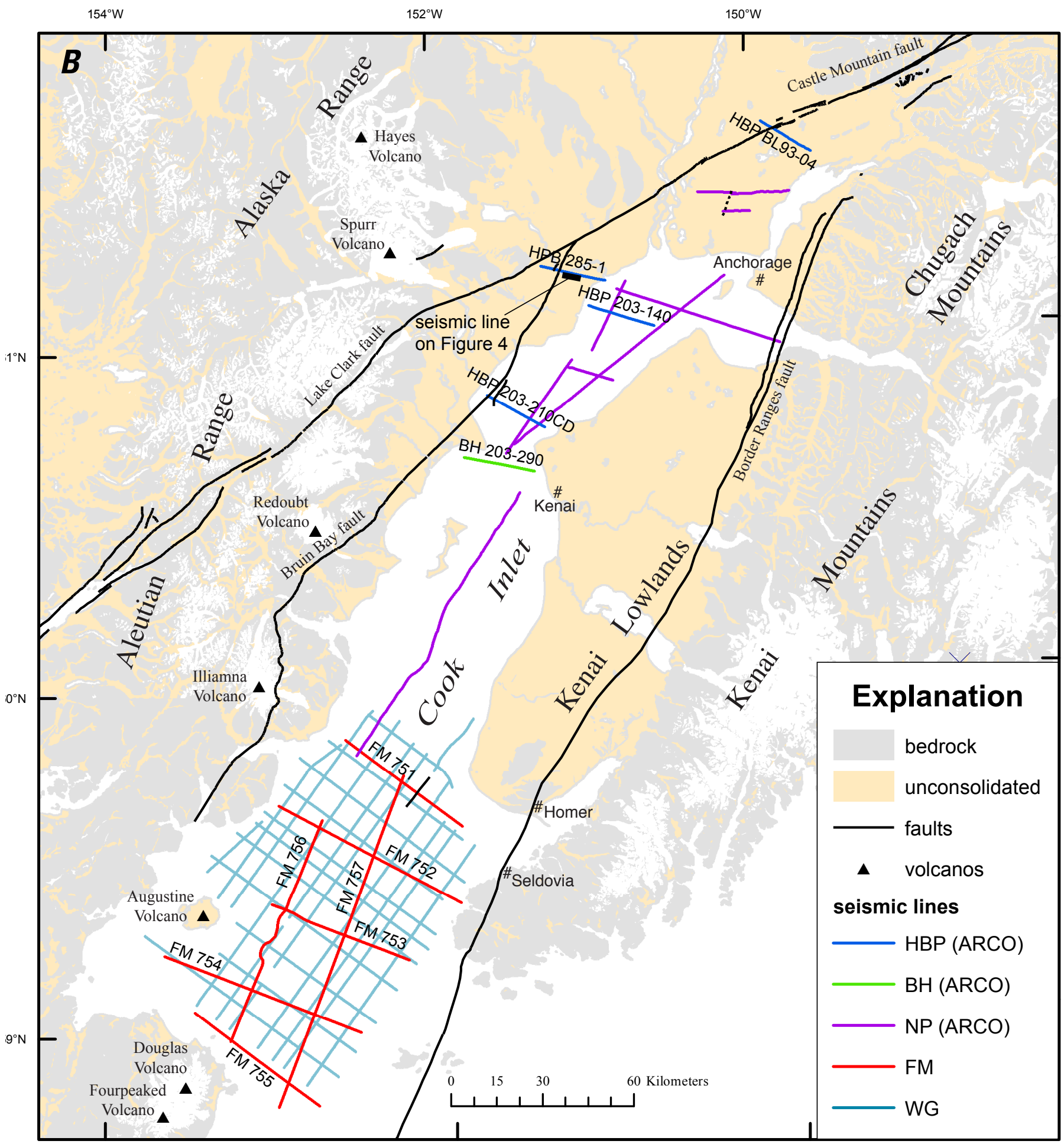

Figure 1.-Continued. 
margin, and rocks of much of the Alaska Range are either arc-derived volcanic or plutonic rocks (Magoon and others, 1976; Plafker and others, 1994). The Tertiary basin fill unconformably overlies both the accretionary complex rocks to the southeast and the volcanic or plutonic rocks to the northwest (Calderwood and Fackler, 1972). Triassic through Upper Cretaceous stratified rocks are inferred to underlie the Tertiary basin fill. These stratified rocks are thought to be related to those that crop out northwest of the Inlet (Magoon and Egbert, 1986).

Tertiary deformation of Cook Inlet basin started between Eocene and early Oligocene time (Barnes and Payne, 1956; Clardy, 1974; Stamatakos and others, 1988; Little and Naeser, 1989; Little, 1990). Deformation in upper Cook Inlet is transpressional and resulted in folds, faults, and eroded horst blocks. Adjacent grabens filled with synfaulted fluvial deposits, and deformation continued until late Miocene to Holocene time (Kirschner and Lyon, 1973; Calderwood and Fackler, 1972; Haeussler and others, 2000). Most deformation appears to be Pliocene to Recent (Haeussler and others, 2000; Bruhn and Haeussler, 2006) and resulted in folds that are doubly plunging, asymmetric, and discontinuous. Kirschner and Lyon (1973) first inferred a genetic link between regional strike-slip faulting and folding after observing that fold hinge lines curve towards the strike of the right-lateral Castle Mountain fault at the northeastern end of the basin. Bruhn and Haeussler (2006) proposed that the basin is being squeezed between the Bruin Bay and Border Ranges faults by right-lateral faulting along the Castle Mountain fault. This geometry results in righttranspressional deformation within the basin.

The Tertiary strata in Cook Inlet were deposited predominantly by alluvial processes, but locally with tidal influence (Calderwood and Fackler, 1972; Flores and Stricker, 1993; Flores and others, 1994, 1997, 1999). Most sediment was derived from erosion of the Alaska Range and Chugach Mountains (Kirschner and Lyon, 1973). The youngest sediments in the basin are unnamed Quaternary deposits, which consist of both glacial and alluvial sediments (fig. 2; Schmoll and others, 1984). The thickness of the Quaternary section is undetermined, partly because no exposures reveal the entire Quaternary section, and partly because oil companies, which have spent the most effort examining the strata of Cook Inlet, have focused on older oil-bearing strata. As a result, the Quaternary sediments commonly are lumped with the uppermost part of the underlying Sterling Formation, which is Pliocene (ReininkSmith, 1995; Dallegge, 2002; Dallegge and Layer, 2004). The Sterling, Beluga, and Tyonek Formations all consist of varying amounts of sandstone, siltstone, shale, and coal, and they likely have interfingering relationships (Swenson, 1997). Dallegge (2002) concluded that the Sterling and Beluga Formations are, at least in part, time equivalent based upon ${ }^{40} \mathrm{Ar} /{ }^{39} \mathrm{Ar}$ dating of tephras. Both the older 'layercake' and the newer time-transgressive views of Cook Inlet stratigraphy are shown in figure 2 .

\section{Data Sources}

Some structures in Cook Inlet are much better known than others, the best-documented are those with drilling related to oil and gas exploration and production. Structural anticlines are the traps for every known oil and gas field in Cook Inlet (for example, Magoon and Claypool, 1981). The Alaska Oil and Gas Conservation Commission (AOGCC) publishes an Annual Report on the status of production from individual fields, and some of these reports contain isopach maps showing the location and extent of a particular structure. The annual report is available online at http://doa.alaska.gov/ ogc/annual/annindex.html (last accessed January 25, 2011). However, the structure contour maps, provided to the AOGCC by the field operators, rarely change from year to year. Thus, it does not matter which version of a recent Annual Report is examined - they all have essentially the same data. We used the 2002 AOGCC report. The compilation of Magoon and others (1976) remains a seminal work on the geology of Cook Inlet, and they had access to some unpublished industry data. Some structures have been illustrated by Fisher and Magoon (1978), Winkler (1992), Haeussler and others (2000), Bruhn and Haeussler (2006), and Fisher and others (2008, 2010), however, other structures are poorly documented. For example, a few of the structures on the map by Magoon and others (1976) apparently were defined by linear trends of dry and abandoned wildcat wells. In some cases, only one or two wells define the location of a structure, and there is no publically available corroborating evidence for its existence. Fisher and Magoon (1978) collected and analyzed seismicreflection data from a coarse grid in lower Cook Inlet. (The term "lower Cook Inlet" is used for the region southwest of West Foreland (fig. 1), and the term "upper Cook Inlet" is used for the region northeast of West Foreland). Fisher and others $(2008,2010)$ interpreted some additional seismic-reflection data from the west side of lower Cook Inlet. Where their new maps overlap those of Fisher and Magoon (1978), they made some minor changes in their interpretation of the region northeast of Augustine Island.

We also utilize a high-resolution aeromagnetic dataset (fig. 3; Saltus and others, 2001; United States Geological Survey, 2002). High-frequency filtered aeromagnetic data image some folds well, because some strata are sufficiently magnetic to create anomalies, particularly in the upper Sterling Formation and Quaternary section. When these strata were folded, they produced linear anomalies along or parallel to the limbs of folds (Saltus and others, 2001). One example of a fold with flanking magnetic anomalies is a syncline adjacent to the Beluga River fold (fig. 4). Modeling indicates that one or more of the horizons imaged on seismic reflection are more magnetic, which produces magnetic anomalies where the relatively magnetic bed(s) are up-turned and truncated on the limbs of the fold. The Middle Ground Shoal, Granite Point, North Cook Inlet, and Beluga River anticlines, for example, are imaged by the aeromagnetic data (fig. 3 folds 22, 17, 14, and 13 , respectively). Other folds are not imaged with the 
aeromagnetic data, such as the Kenai and Sterling fields (fig. 3 folds 31 and 30, respectively). Therefore, the absence of an aeromagnetic signature does not necessarily mean that a fold is absent, but rather that the magnetic strata that would produce magnetic anomalies are absent. The position of the magnetic marker bed(s) relative to the crest of the anticline as well as the thickness and magnetic intensity of the bed(s), also will cause variation in the geometry and amplitude of the magnetic anomalies associated with an individual structure.

Although the source of magnetic layering within the Sterling Formation and Quaternary section has not been studied sufficiently, outcrop measurements of magnetic susceptibility in these units (Altstatt and others, 2002; Saltus and Haeussler, 2004) show values consistent with the aeromagnetic anomalies produced. It is our judgment that these layers are the result of magnetite concentration in highenergy deposits. Bruhn and Neuffer (unpublished report 2002) found magnetite, hematite, and pyrrhotite in two subsurface samples of the Tyonek Formation. They also attempted to determine the magnetic carrier of one of the samples through thermal demagnetization of an isothermal remanence. The sample had only 13 percent of its initial remanence at $351^{\circ} \mathrm{C}$, which suggests that pyrrhotite is a likely carrier of some of the remanence. Above this temperature, the sample was chemically altered and increased its remanent intensity. Nonetheless, the present-day beach sand at Nikiski, for example, is very dark, magnetic (values generally greater than $5 \times 10^{-3} \mathrm{SI}$ ), and contains magnetite. This observation indicates

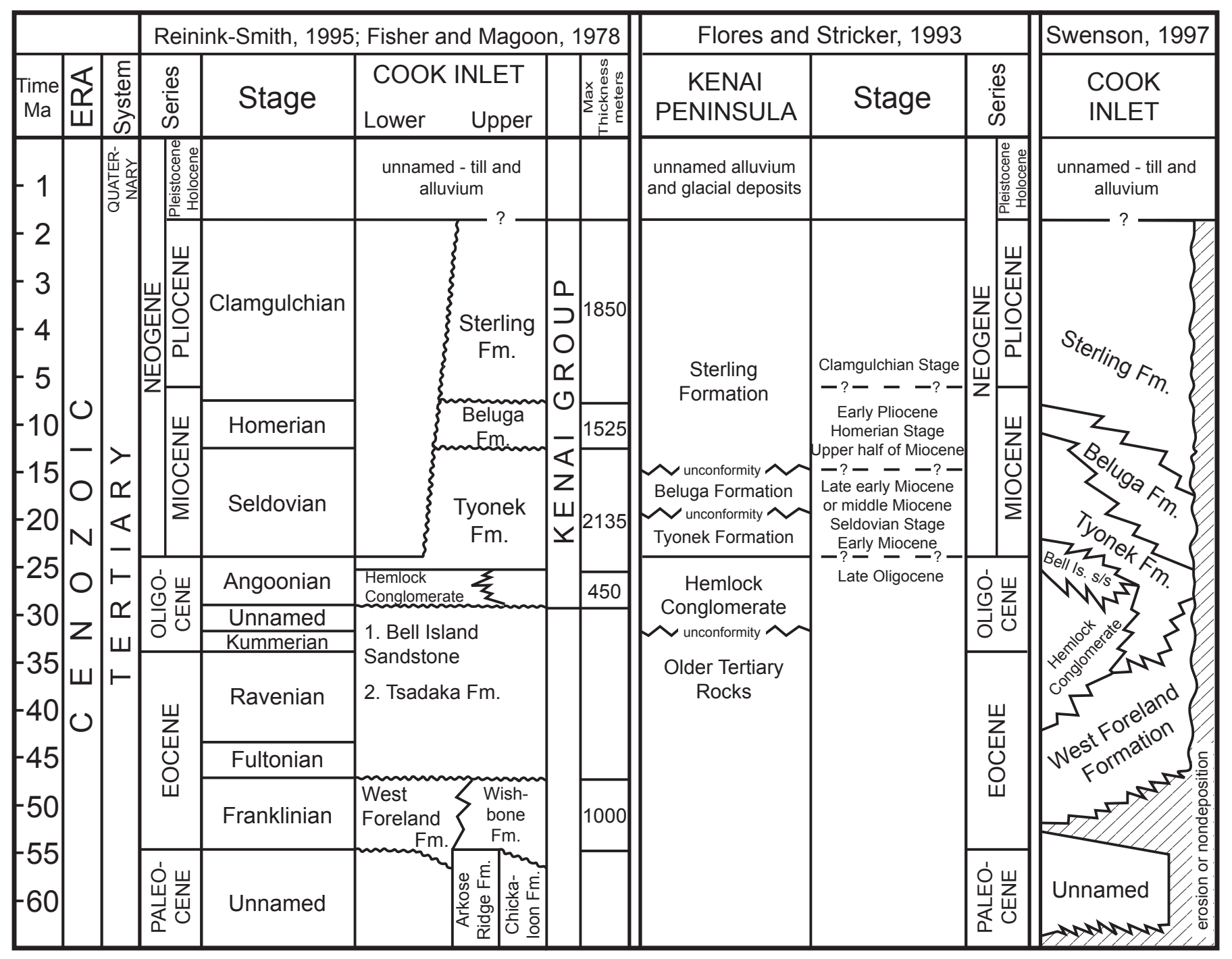

Figure 2. Three views of the stratigraphic column for Tertiary Cook Inlet Basin sediments, from Dallegge and Layer (2004). ${ }^{40} \mathrm{Ar} /{ }^{39} \mathrm{Ar}$ dating by Dallegge (2002) and Dallegge and Layer (2004) support the time-transgressive interpretation of Cook Inlet stratigraphy of Swenson (1997). 


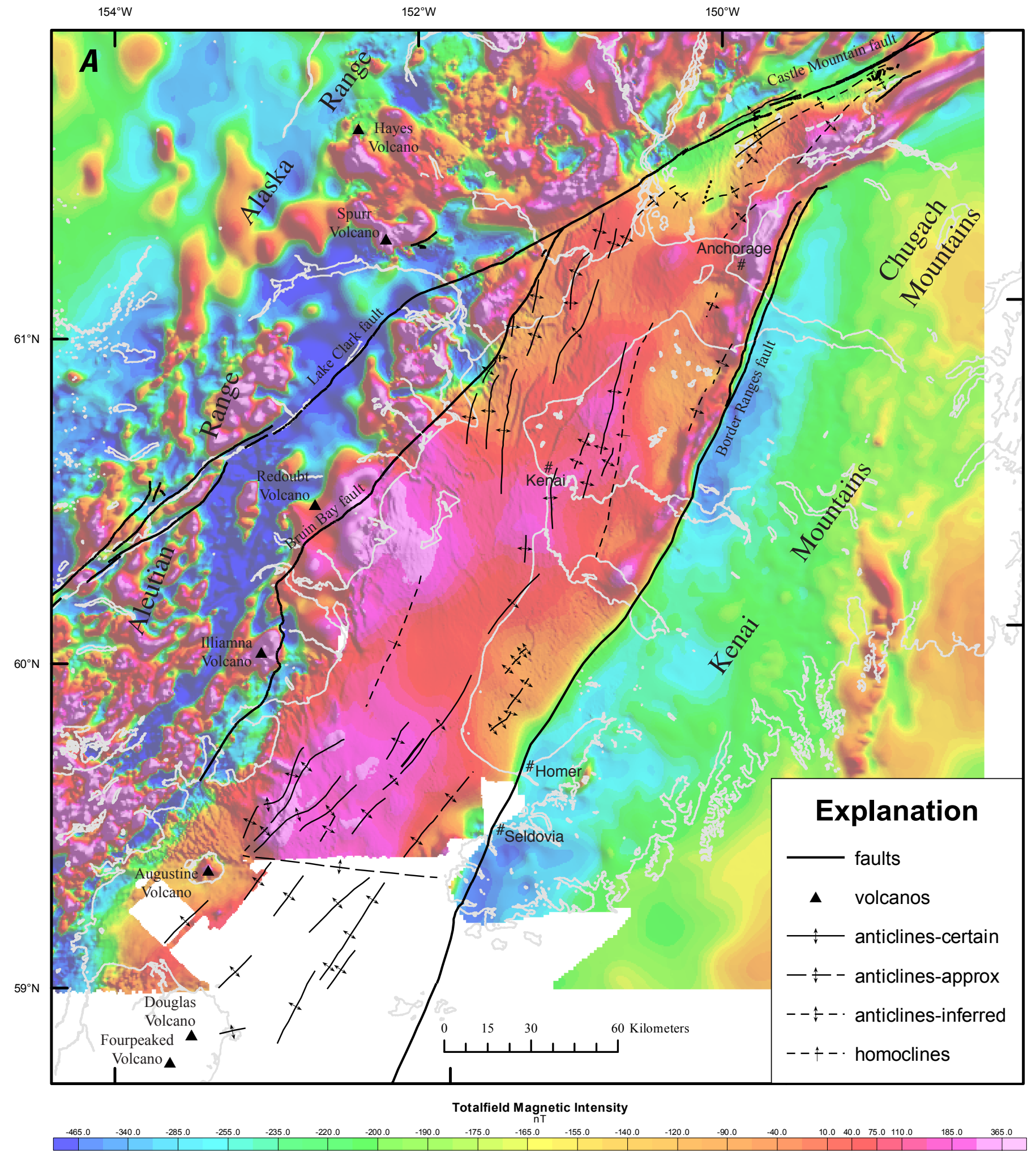

Figure 3. Magnetic maps of the Cook Inlet region, with faults and folds shown as on figure $1 A$, listed in table 1 , and discussed in the text. High resolution data from Saltus and others (2001) and U.S. Geological Survey (2002). A, Total field magnetic intensity map. Low resolution regional data from Saltus and Simmons (1997). $B$, Band-pass filtered magnetic intensity map for region of high resolution data. Data is the "bandpass filter 1" from Saltus and others (2001). 


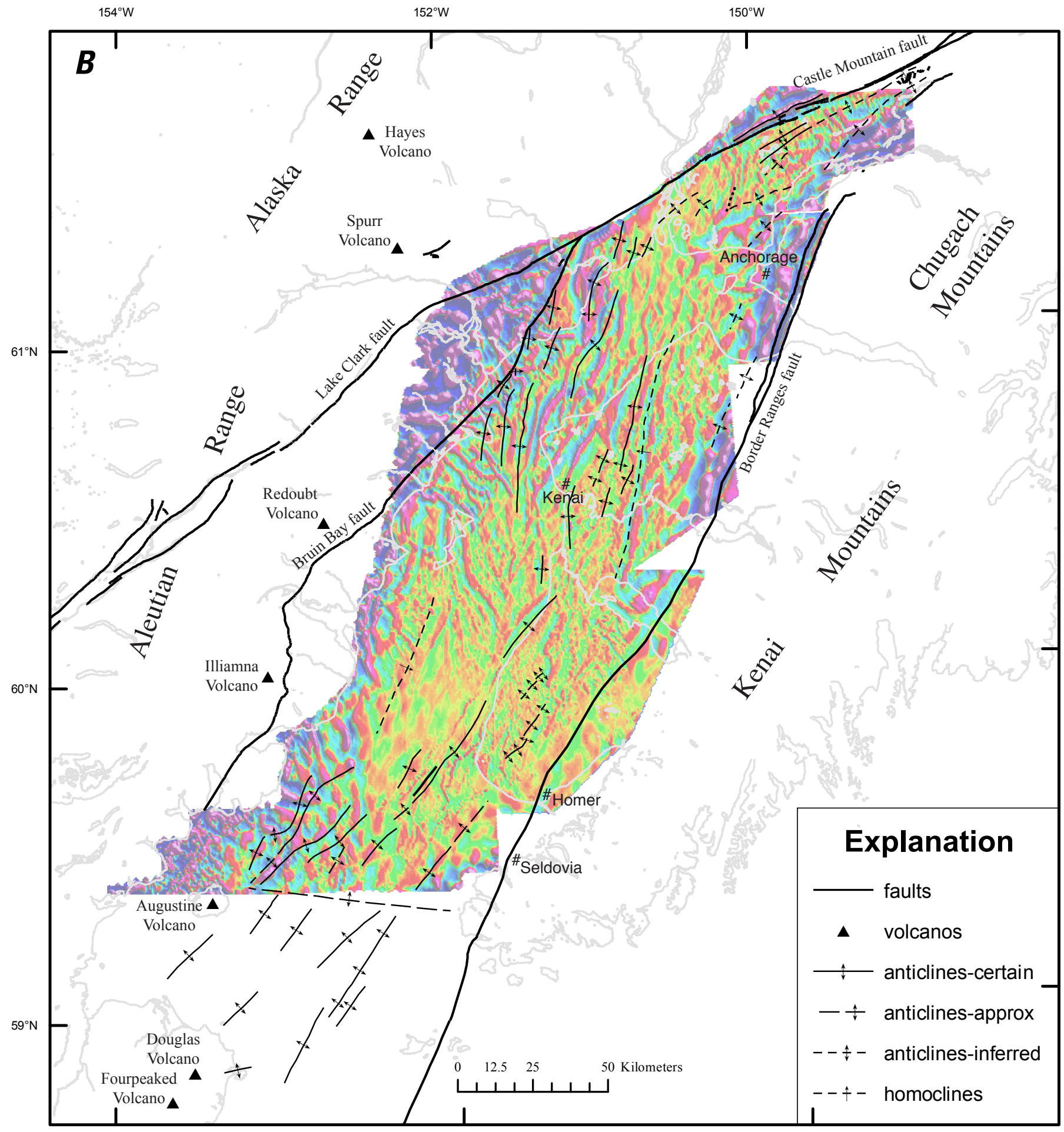

Bandpass filtered magnetic intensity

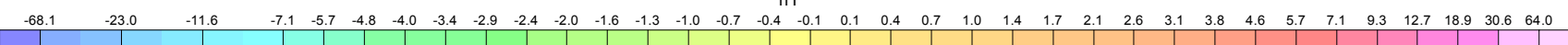

Figure 3.-Continued. 
that magnetite is a common magnetic mineral in the Tertiary sediments, and it likely is responsible for most of the induced magnetization.

Three seismic-reflection datasets constrain our interpretation (fig. 1). Our work focused on upper Cook Inlet, an area for which little previous work has been published.

We examined seismic-reflection profiles donated to the U.S. Geological Survey and University of Utah by ARCO Alaska, Inc. Some of these profiles were published in Haeussler and others (2000), and there is a line drawing of another profile in Bruhn and Haeussler (2006). Additional unpublished lines were used to guide interpretation. Fisher and Magoon (1978) first interpreted and published seismic data from lower Cook Inlet. Recently, Fisher and others $(2008,2010)$ interpreted and published another dataset from lower Cook Inlet. These papers are focused on deformation of the western part of lower Cook Inlet. Where there are differences between the interpretations of Fisher and Magoon (1978) and Fisher and others (2008, 2010), we adopt the latter. The high-resolution aeromagnetic survey overlaps the northernmost lines of their seismicreflection profiles, but is not particularly helpful in discerning structures. Therefore, in the absence of additional data we use their interpretations almost without modification for the southern part of the study area.

\section{Tertiary Structures in Cook Inlet}

A summary of the characteristics of Tertiary structures in Cook Inlet is shown on figure 1 and listed in table 1. Structures also are shown on aeromagnetic maps in figure 3. In the following section, we discuss aspects of each structure that fail to fit neatly or concisely into the data table. In particular, we discuss and evaluate the quality of the data that document the lesser-known structures. In general, the more poorly defined structures are inferred by tracing anticline crests between the locations of wildcat wells. In the absence of any other data this may be reasonable, but one can be much

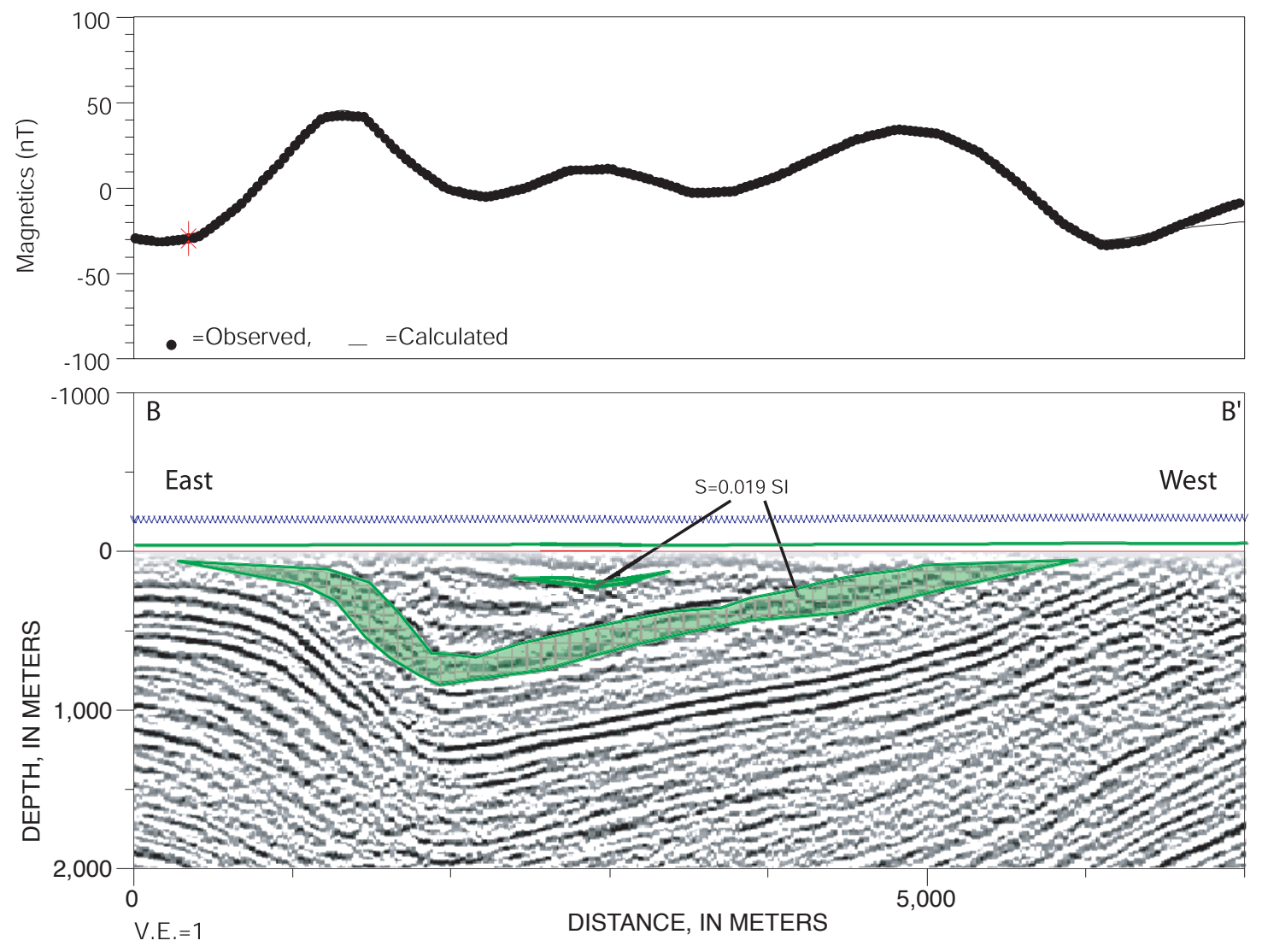

Figure 4. Detailed two-dimensional magnetic model along part of seismic line 285-1, Cook Inlet Basin, Alaska, from Saltus and others (2001). Seismic line location is shown on figure $1 B$. The magnetic layers generally follow the seismic layering and have a susceptibility of $19 \times 10-3 \mathrm{SI}$. This shows that prominent high-frequency magnetic anomalies can be a product of folding. 
Table 1. Anticlines in the Cook Inlet Basin, Alaska.

[AOGCC, Alaska Oil and Gas Conservation Commission; DOG, Alaska Department of Oil and Gas]

\begin{tabular}{|c|c|c|c|c|c|}
\hline $\begin{array}{c}\text { Name of structure and label on } \\
\text { Figure 1A }\end{array}$ & $\begin{array}{l}\text { Length, in } \\
\text { Kilometers }\end{array}$ & Evidence for structure & Comment on shape of structure & Data source & $\begin{array}{c}\text { Confidence of } \\
\text { existence of } \\
\text { structure }\end{array}$ \\
\hline (1) Castle Mountain fault anticline & 34 & seismic, aeromag, wildcat wells & cored by steeply dipping faults, $4-\mathrm{km}$ wide & $\begin{array}{l}\text { Saltus and others, 2001; Haeussler and others } 2000 \text {; } \\
\text { this study }\end{array}$ & certain \\
\hline (2) Big Lake North & 18 & seismic & very broad antiform & this study & certain \\
\hline (3) Pitman & 63 & seismic, four wildcat wells & very broad antiform & $\begin{array}{l}\text { Kirschner and Lyon, 1973; Magoon and others, } \\
\text { 1976; this study }\end{array}$ & certain \\
\hline (4)Wasilla St. No. 1-Needham & 46 & three wildcat wells & unknown & Magoon and others, 1976 & poor \\
\hline (5) Fish Creek - Knik Arm No. 2 & 16 & aeromag, two wildcat wells & unknown & this study & poor \\
\hline (6) Lorraine-Knik Arm State No. 1 & 18 & two wildcat wells & unknown & Magoon and others, 1976; this study & poor \\
\hline $\begin{array}{l}\text { (7) Middle Lake Unit No. 1-Alaska } \\
\text { Gulf No. } 1\end{array}$ & 23 & four wildcat well, trend inferred from aeromag & unknown & Magoon and others, 1976; this study & fair \\
\hline (8) Figure Eight Unit No. 1 & 10 & one wildcat well, trend inferred from aeromag & unknown & Magoon and others, 1976 & poor \\
\hline (9) Bell Island & 18 & one wildcat well, trend inferred from aeromag & unknown & Magoon and others, 1976 & poor \\
\hline (10) Stump Lake & 7 & gas field, trend inferred from aeromag & doubly plunging elongate dome & AOGCC; this study & certain \\
\hline (11) Ivan River( & 11 & gas field, trend inferred from aeromag & doubly plunging antiform & AOGCC; this study & certain \\
\hline (12) Lewis River & 13 & gas field, trend inferred from aeromag & antiform between two thrusts & AOGCC; this study & certain \\
\hline (13) Beluga River & 22 & gas field, seismic, aeromag & doubly plunging curving fault-cored fold & $\begin{array}{l}\text { AOGCC; Haeussler and others, 2000; Saltus and } \\
\text { others, 2001; this study }\end{array}$ & certain \\
\hline (14) North Cook Inlet-SRS & 40 & gas field, seismic, aeromag & fault-cored fold; limb dip to $70^{\circ}$ & $\begin{array}{l}\text { AOGCC; Haeussler and others, 2000; Saltus and } \\
\text { others, 2001; this study }\end{array}$ & certain \\
\hline (15) Moquawkie & 12 & oil field & unknown & AOGCC & fair \\
\hline (16) Nicolai Creek & 7 & gas field & unknown & AOGCC & good \\
\hline (17) Granite Point & 15 & oil field & fault-cored fold; limb dip to $90^{\circ}$ & $\begin{array}{l}\text { AOGCC; Haeussler and others, 2000; Saltus and } \\
\text { others, 2001; this study }\end{array}$ & certain \\
\hline (18) North Trading Bay & 3 & oil field & unknown & AOGCC & certain \\
\hline (19) Trading Bay & 9 & oil field, seismic & $\begin{array}{l}\text { doubly plunging curving assymetric } \\
\text { anticline; one cross fault }\end{array}$ & AOGCC; this study & certain \\
\hline (20) West McArthur River & 18 & oil field; seismic & fault-cored fold & AOGCC; this study & certain \\
\hline (21) McArthur River-Redoubt Shoal & 27 & oil field, seismic, aeromag & doubly plunging broad antiform, cross faults & AOGCC; this study & certain \\
\hline (22) Middle Ground Shoal & 44 & oil field, seismic, aeromag & fault-cored fold & AOGCC; this study & certain \\
\hline (23) Beaver Creek & 14 & gas field, trend inferred from aeromag & $\begin{array}{l}\text { smaller anticline on margin of Swanson } \\
\text { River fold, tight syncline in between }\end{array}$ & AGOCC; Magoon and others, 1976; this study & certain \\
\hline (24) Swanson River & 40 & oil field, aeromag & anticline with numerous cross faults & AGOCC; Magoon and others, 1976; this study & certain \\
\hline (25) Kenai Lowlands & 85 & aeromag linear & long E-dipping monocline(?) & this study & fair \\
\hline (26) Turnagain Arm & 9 & one wildcat well & possible fold on basement high & Hartman and others, 1972 ; this study & poor \\
\hline (27) Pincher Creek & 15 & unknown & unknown & Magoon and others, 1976 & poor \\
\hline (28) Swan Lake & 17 & one wildcat well & unknown & Magoon and others, 1976 & poor \\
\hline (29) West Fork & 11 & gas field & unknown & AOGCC; Magoon and others, 1976 & certain \\
\hline (30) Sterling & 10 & gas field & probably a broad anticline & AOGCC; Magoon and others, 1976 & certain \\
\hline (31) Kenai-Cannery Loop & 21 & gas field, weak aeromag anomalies & almost symmetric anticline & $\begin{array}{l}\text { AOGCC; DOG; Magoon and others, 1976; this } \\
\text { study }\end{array}$ & certain \\
\hline (32) Kasilof & 9 & four wells, weak aeromag anomalies & unknown & Magoon and others, 1976; this study & certain \\
\hline (33) Falls Creek-Ninilchik & 27 & 13 wells, aeromag, DOG unit map & likely has three anticlinal crests & AOGCC; Magoon and others, 1976; this study & certain \\
\hline (34) Deep Creek-Happy Valley & 12 & 8 wells & $\begin{array}{l}\text { probable left step between Deep Creek and } \\
\text { Happy Valley areas }\end{array}$ & Magoon and others, 1976 & fair \\
\hline (35) Kalgin Island South & 49 & aeromag linear, seismic & east-dipping monocline & this study & fair \\
\hline (36) Starichkof (Cosmopolitan) & 50 & gas wells, seismic, aeromag, DOG unit map & broad anticline & Fisher and Magoon, 1978; this study & certain \\
\hline (37) North Fork-Nikolaevsk & 15 & 5 wells, bedrock geology, DOG unit map & likely has two anticlinal crests & AOGCC; DOG; Magoon and others, 1976 & certain \\
\hline (38) Iniskin & 15 & seismic, aeromag, wells & broad fold & Fisher and Magoon, 1978 & certain \\
\hline (39) Chinitna Point West & 40 & seismic & broad fold & Fisher and others, 2010 & certain \\
\hline (40) Chinitna Point East & 52 & seismic & broad fold & Fisher and Magoon, 1978; Fisher and others, 2010 & certain \\
\hline (41) Hawk & 40 & seismic & broad fold & Fisher and Magoon, 1978; Fisher and others, 2010 & certain \\
\hline (42) East of Raven & 25 & seismic & unknown & Fisher and others, 2010 & certain \\
\hline (43) West of LCI COST No. 1 & 10 & seismic & unknown & Fisher and others, 2010 & certain \\
\hline (44) Starichkof Southwest & 17 & seismic, aeromag & unknown & $\begin{array}{l}\text { Fisher and Magoon, 1978; Fisher and others, 2010; } \\
\text { this study }\end{array}$ & certain \\
\hline (45) Kachemak & 38 & seismic, aeromag, one wildcat well & unknown & $\begin{array}{l}\text { Fisher and Magoon, 1978; Fisher and others, 2010; } \\
\text { this study }\end{array}$ & certain \\
\hline (46) Seldovia Arch & 68 & seismic & $\begin{array}{l}\text { very broad uplift perpendicular to other } \\
\text { structures }\end{array}$ & Fisher and Magoon, 1978 & certain \\
\hline (47) Augustine East & 16 & seismic & unknown & Fisher and others, 2010 & certain \\
\hline (48) Augustine Far East & 18 & seismic & unknown & Fisher and others, 2010 & certain \\
\hline (45) Lower Cook Inlet North & 11 & seismic & unknown & Fisher and Magoon, 1978 & certain \\
\hline (49) LCI Middle & 28 & seismic & broad fold & Fisher and Magoon, 1978 & certain \\
\hline (50) Loon & 40 & seismic & broad fold & Fisher and Magoon, 1978 & certain \\
\hline (51) Southeast Loon & 17 & seismic & unknown & Fisher and Magoon, 1978 & certain \\
\hline (52) Teal & 28 & seismic & $\begin{array}{l}\text { broad fold, tighter than most in the lower } \\
\text { Inlet }\end{array}$ & Fisher and Magoon, 1978 & certain \\
\hline (53) Shaw Island & 16 & seismic & unknown & Fisher and Magoon, 1978 & certain \\
\hline (54) Kamishak Bay & 12 & seismic & unknown & Fisher and Magoon, 1978 & certain \\
\hline (55) Sukoi Bay & 9 & onshore geology & broad anticline & Magoon and others, 1976 & certain \\
\hline
\end{tabular}


more confident in the presence of a structure if it also is observed on seismic-reflection profiles and (or) aeromagnetic data. Aeromagnetic images of structures provide important tools for tracing structures on a regional scale, in contrast to a seismic-reflection profile that provides detailed cross-sectional information. We use published names for structures, where available, and we assign informal names for unnamed structures using either well names or local geographic features. The following discussion proceeds in the order the structures are listed on table 1, which is from north to south. Only anticlines are discussed in the section on folds. In addition, this report is not meant to be a complete description of each structure, but rather is intended to show the interpreted location and length. The casual reader may wish to skip this description section and proceed to the Discussion.

\section{Faults}

All faults are shown on figures 1 and 3 and are identified by a letter.

\section{Castle Mountain Fault}

The Castle Mountain fault (fault A, figs. 1, 3) is recognized in bedrock in the Talkeetna Mountains (Detterman and others, 1976a; Fuchs, 1980). The western part of the fault has a Holocene fault scarp (Detterman and others, 1974; Haeussler, 1998; Willis and others, 2007). The fault has a history extending back at least 47 million years (Parry and others, 2001). Perhaps more individual studies have been published on the Castle Mountain fault than any other structure in the basin because of ease of access to the fault and exposures in the Talkeetna Mountains (Parry and others, 2001; Bruhn and others, 2000; Bunds, 2001; Haeussler and others, 2000, 2002). South-facing Holocene scarps define the active fault trace from the area near Houston westward to the Susitna River. Discontinuous scarps define the fault between Houston and the road to Hatcher Pass, but no faultline scarps have been identified east of the Hatcher Pass Road. The extent of the fault was mapped by Detterman and others (1974, 1976a), Clardy (1974), and Haeussler (1998). Historical earthquakes in 1984 (Lahr and others, 1986) and 1996 had right-lateral offset along the part of the fault without a scarp. The fault dips steeply to the north and has had both right-lateral and north-side-up dip-slip offset (Detterman and others, 1974; Haeussler and others, 2002). At its western end, the Castle Mountain fault connects with the Lake Clark fault (Detterman and others, 1976b). Haeussler and Saltus (2005) infer $26 \mathrm{~km}$ of right-lateral offset on the Lake Clark fault in the last $\sim 35 \mathrm{Ma}$, based on offset aeromagnetic features, and a similar or greater amount of offset on the Castle Mountain fault also would have occurred. Willis and others (2007) found an outwash channel right-laterally offset $36 \mathrm{~m}$ across the fault. They infer an age of 11,300 to 13,470 calendar years B.P. for the feature, which yields a modern slip rate of $0.27-0.32 \mathrm{~cm} / \mathrm{yr}$ Additional studies on the Castle Mountain fault were published by Detterman and others (1975), Bruhn (1979), Bruhn and Pavlis (1981), Fuchs (1980), Bunds (2001), and Parry and others (2001).

\section{Wishbone Hill Faults}

At Wishbone Hill (faults B, figs. 1, 3), a syncline was elevated above the valley floor, possibly by shortening of the rocks beneath one or both sides of the fold (Barnes and Payne, 1956; Bunds, 2001). This fold is the most easily seen and visited in the entire basin. The fold appears to have formed due to shortening across the northeastern corner of the basin. When the syncline is viewed looking westward, it provides a down-plunge view of the basin strata. At Wishbone Hill (faults B, figs. 1, 3), north-south striking cross faults cut a syncline (Bunds, 2001). Similar cross faults have been recognized or inferred in the subsurface of many of the folds in Cook Inlet, perhaps most notably in the Swanson River field, as well as the McArthur River, Trading Bay, and Redoubt Shoal fields.

\section{Lake Clark Fault}

The Lake Clark fault (fault C, figs. 1, 3) is along strike from, and connects with, the Castle Mountain fault near the Beluga River. The Lake Clark fault cuts through Tertiary granitic rocks in the region south of Spurr Volcano. Haeussler and Saltus (2005) found that the regional trends of aeromagnetic anomalies are offset about $26 \mathrm{~km}$ across the Lake Clark fault, and they infer that $\sim 35 \mathrm{Ma}$ intrusives are responsible for the magnetic anomalies. Schmoll and Yehle (1987) found that a small part of the Lake Clark fault, which they referred to as the Lone Ridge fault (located near the "3" in fig. 1), has a prominent geomorphic scarp, which they suggest is evidence of an active fault trace. They also suggest that a sequence of Quaternary moraines is offset across the fault. Reger and Koehler (2009) reassessed the evidence for offset moraines. They concluded the moraines were offset 25 $m$ vertically (south-side down), and they inferred the moraines likely are marine isotope stage 4 or 6 age (that is, about 65 kya or 150 kya, respectively (Martinson and others, 1987)) . Like previous workers (Plafker and others, 1975), Reger and Koehler (2009) found no evidence of Holocene offset along the fault. Because the Castle Mountain fault has evidence of Holocene offset and the Lake Clark fault does not, this relationship suggests that deformation is being transferred on to Cook Inlet folds and faults south of the Lake Clark-Castle Mountain fault junction (Bruhn and Haeussler, 2006).

\section{Bruin Bay Fault}

The Bruin Bay fault (fault D, figs. 1, 3) flanks the northwestern edge of Cook Inlet and joins the Castle Mountain-Lake Clark fault system near the Beluga River. The fault is a southeast-directed thrust fault in outcrop along 
the Beluga and Chuitna Rivers (Magoon and others, 1976). It is inferred to run beneath Trading Bay, and to the southwest it lies near the western margin of Cook Inlet. Near Redoubt Volcano the fault is found again in outcrop, where it offsets Jurassic rocks (Detterman and Hartsock, 1966). A seismicreflection profile in the vicinity of the Beluga gas field shows that it is a steeply west-dipping fault (Haeussler and others, 2000). On a structure-contour map of the Trading Bay oil field, provided by the operator to the AOGCC, a "west Trading Bay fault" was mapped adjacent to the field on the northwest side. This fault is probably the Bruin Bay fault, as mapped by Magoon and others (1976). Southwest of southern Cook Inlet the Bruin Bay fault is intruded by a 26-27 Ma pluton (Magoon and others, 1976). The fact that the Bruin Bay fault cuts Beluga Formation sediments near its junction with the Castle Mountain fault indicates the oldest age of movement on the northern part of the fault is younger than when movement ceased in lower Cook Inlet. No Holocene fault scarps lie along the fault (Detterman and others, 1975).

\section{Border Ranges Fault}

The Border Ranges fault (fault E, figs. 1, 3) juxtaposes rocks of the accretionary complex of the Chugach and Kenai Mountains from the backstop rocks of the Peninsular terrane, which mostly consist of Jurassic volcanic and intrusive rocks (for example, Pavlis, 1982; Plafker and others, 1994). In the Matanuska Valley the fault has right-lateral offset of Tertiary age (Little and Naeser, 1989; Little, 1990), but there, and further to the southwest, it must have been a normal or normal-oblique fault in Tertiary time. We depict the fault as a normal fault, which we suggest was the last phase of motion along the fault. Three lines of evidence support this inference. First, Mesozoic rocks of the Kenai and Chugach Mountains are topographically above the Tertiary sediments of the Cook Inlet basin. There must have been northwest-side-down movement in Tertiary time. Second, aeromagnetic data do not support interpretation as a thrust fault. The accretionary complex rocks along the east side of the fault are almost nonmagnetic. The Mesozoic metavolcanic rocks (for example, Detterman and Hartsock, 1966), just to the east of the fault, are slightly magnetic (Alstatt and others, 2002). However, a strong magnetic anomaly lies just west of the trace of the Border Ranges fault in bedrock, which is likely related to Jurassic mafic intrusions (for example, Burns, 1982). In the Anchorage area, the eastern contact of the flanking aeromagnetic high is very linear, which indicates that it is a fault contact. Third, southeast of Anchorage, the flanking aeromagnetic high lies west of the surface trace of the Border Ranges fault. This is probably caused by there being some thickness of the nonmagnetic Peninsular terrane rocks lying between the east side of the anomaly and the surface trace of the Border Ranges fault. The relationships can be explained by one west dipping normal fault or two normal faults, or both. Therefore, there is no evidence that the accretionary complex was thrust over the inferred Jurassic intrusive rocks. The timing of the faulting is not clear. Evidence for normal faulting was not found on seismic-reflection profiles to the southeast of the study area across the Border Ranges fault (for example, Mackevitt and Plafker, 1974, Pavlis, 1982), and there is no evidence for Holocene faulting along the Border Ranges fault (Haeussler and Anderson, 1997).

The aeromagnetic data are useful for constraining the trace of the Border Ranges fault on the Kenai Peninsula where no outcrops of the Peninsular terrane rocks are found. As discussed above, in the Anchorage area and to the northeast, the Border Ranges fault lies on the east, or southeast side of the magnetic high that correlates with Jurassic intermediate to mafic intrusive rocks. To the southwest of Anchorage, the Border Ranges fault is not constrained by outcrops, until the western tip of the Kenai Peninsula near Seldovia, where the fault juxtaposes different Mesozoic rock units (for example, Bradley and others 1999; Hawley, 1992). Outcrop relationships near Seldovia reveal Cook Inlet basin Tertiary sediments on both sides of the Border Ranges fault, and depositionally on top of the Mesozoic accretionary prism rocks (Martin and others, 1915; Bradley and others, 1999), but the relationships do not clarify the fault's sense of slip. Limited aeromagnetic coverage in this region indicates an aeromagnetic high lies on the northeast side of the fault - as in the Anchorage area. On the basis of these observations, it appears reasonable to infer the location of the Border Ranges fault in the subsurface as lying on the southeast side of the prominent aeromagnetic anomaly (fig. 3). If so, the Tertiary Cook Inlet Basin sediments lie on either side of the inferred fault trace (Bradley and others, 1999). Beluga Formation outcrops just west of Homer show no evidence of its presence.

From the Anchorage area toward Homer, the magnetic high along the Border Ranges fault diminishes in amplitude. The reason for this is not certain, but it seems likely that it is related to a decreased size or an absence of the Jurassic intermediate to mafic intrusives.

\section{Little Susitna River Escarpment}

This escarpment is a $15-\mathrm{km}$-long linear feature that lies east of the Little Susitna River, (feature F, figs. 1, 3). The escarpment is unusually long and linear, and it is consistently east-side-up and about $3 \mathrm{~m}$ high. These characteristics are consistent with the surface expression of an active fault trace. Alternatively, the escarpment may be related to downcutting of the Little Susitna River during late Quaternary or early Holocene deglaciation. There is another curving escarpment on the other (west) side of the Little Susitna River, which has a similar height and geomorphic position. However, it is arcuate, indicating it is related to fluvial processes, and it appears to be a terrace riser. This relationship indicates the Little Susitna River escarpment also is a terrace riser and not an active fault scarp. We, thus, favor the fluvial origin for the scarp, but mention it here for completeness. There is no evidence for a fault at the north end of the scarp on poor-quality seismic-reflection profiles. 


\section{Capps Glacier Fault}

A fault between Mesozoic and Tertiary rocks east of Spurr Volcano was first mapped by Barnes (1966) and then included in a compilation by Magoon and others (1976) (feature G, figs. 1, 3). Gillis and others (2009) considered the fault a significant basin-bounding fault, with some component of right-lateral slip. The fault juxtaposes Paleocene intrusions and Eocene West Foreland Formation. Thus, the fault is Eocene or younger. The western extension of the fault is covered by Holocene volcanic deposits from Spurr Volcano.

\section{Lower Cook Inlet Faults}

Fisher and Magoon (1978) mapped a number of thrust faults associated with folds in lower Cook Inlet, and minor changes to these interpretations appear in Fisher and others $(2008,2010)$. These faults are shown on figures 1 and 3 . The only dated section nearby is in the COST well, which has Eocene strata at a depth of $413 \mathrm{~m}$ beneath the surface (Turner, 1986), thus, the faults are constrained only to be active after Eocene time.

\section{Folds}

In contrast to faults, folds are numbered on figures 1 and 3. All folds are concealed by surficial deposits, but the map legend uses exposed fold symbols for greater clarity.

\section{Castle Mountain Fault Anticline}

A 4-km-wide anticline on the north side of the Castle Mountain fault was noted by Haeussler and others (2000) on a seismic-reflection profile (feature 1, figs. 1,3). They interpreted this anticline as being cored by several steeply dipping faults. Wildcat wells drilled on the crest of this feature penetrate Miocene Tyonek Formation sediments, and thus, the anticline is younger than Miocene. An aeromagnetic high parallels the surface trace of the Castle Mountain fault in the region near Houston, and this high correlates with the location of the anticline as shown by the seismic-reflection profile in Haeussler and others (2000). The aeromagnetic high may be related to the uplift of more magnetic basement rocks in the core of the anticline. Therefore, we infer the lateral extent of the anticline is, at minimum, the same as the extent of the aeromagnetic anomaly. It is possible that this anticline extends to the southwest and is responsible for the large westward bend of the Susitna River just north of the Castle Mountain fault, as first hypothesized by Kelly (1961).

\section{Big Lake North}

This feature is based on a broad antiform observed on a seismic-reflection profile (Haeussler and others, 2000), with one well drilled on it (feature 2, figs. 1,3). The lateral extent and orientation are suggested by a weak aeromagnetic high extending between this feature and the Castle Mountain fault.

\section{Pitman}

A long curving anticline was mapped by Magoon and others (1976) and apparently was inferred by tracing a line through four wildcat wells (feature 3, figs. 1, 3). We divide this anticline into the Pitman fold and the Middle Lake Unit No. 1 fold (feature 7), based on weak trends in high-frequency filtered aeromagnetic data. These trends do not parallel the geometry of the fold axes in Magoon and others (1976). Kirschner and Lyon (1973) also portrayed this feature as two folds, similar to our interpretation. This structure is a broad anticline on seismic-reflection profiles. We extend the structure east of the north side of the Wishbone Hill syncline (fig. 1), based on the aeromagnetic expression.

\section{Wasilla State No. 1—Needham}

This anticline was mapped by Magoon and others (1976) and is suggested by three aligned wildcat wells, all of which were dry holes (feature 4, figs. 1, 3). There is no indication of a fold on the aeromagnetic data, and we do not have seismicreflection data that cross its inferred location. The southern part of the fault parallels a large aeromagnetic anomaly at the southeastern boundary of the Cook Inlet Basin, which locally appears to be related to Jurassic intrusive rocks (for example, Saltus and others, 2001). The extent of this structure is the same as that mapped by Magoon and others (1976), except we extend the structure east of the south side of the Wishbone Hill syncline (fig. 1).

\section{Fish Creek—Knik Arm No. 2}

This small structure is indicated by two wildcat wells and by a northeast trend of aeromagnetic anomalies, which parallels other structures to the north (feature 5, figs. 1, 3). The inferred trend of the structure does not cross any seismicreflection profiles to which we have access.

\section{Lorraine-Knik Arm State No. 1}

This anticline was mapped on Magoon and others (1976) compilation between three aligned wildcat wells (feature 6 , figs. 1, 3). Seismic reflection data show no indication of an anticline near the northernmost well, and therefore, we reduced the length of the structure from that mapped by Magoon and others (1976). There is no indication of a fold on the aeromagnetic data.

\section{Middle Lake Unit No. 1—Alaska Gulf No. 1}

This structure is suggested by four aligned wildcat wells, by a broad anticline on an unpublished seismic line, 
and by vague trends in the aeromagnetic data (feature 7, figs. 1, 3). The Middle Lake Unit No. 1 well and the Alaska Gulf No. 1 well are on either end of the four aligned wildcat wells. An east-west trending seismic-reflection profile shows thinning of Tertiary strata near the inferred fold axis. Another seismic-reflection profile stops at the inferred trace of the fold and does not reveal its presence. Thus, it is difficult to verify the existence of this structure. There is a northeast-southwest trending feature in the aeromagnetic data beneath the inferred fold. Elsewhere in the basin, these aeromagnetic features typically are on the flanks of folds. Nonetheless, we use the trend of the aeromagnetic anomalies to guide the orientation and length of this structure.

\section{Figure Eight Unit No. 1}

The only evidence for this structure is the Figure Eight Unit No. 1 well, which was a dry hole (feature 8, figs. 1, $3)$. We find no evidence for a fold on an east-west seismicreflection profile $5 \mathrm{~km}$ north of the Figure Eight well. We use northeast-trending aeromagnetic anomalies in this region to infer the orientation of the feature.

\section{Bell Island}

The Bell Island structure was mapped by Magoon and others (1976) based on the presence of the Bell Island well (feature 9, figs. 1, 3). The inferred orientation of the structure parallels trends in the high-frequency filtered aeromagnetic data, but it is not expressed like the Beluga fold (feature 13). We are uncertain of the presence of a structure here.

\section{Stump Lake}

The Stump Lake gas field was discovered in 1978 and according to a structure contour map provided by the field operator for the AOGCC annual summary the structure is about $5 \mathrm{~km}$ long (feature 10, figs. 1, 3). High-frequency filtered aeromagnetic anomalies trend north-northeasterly in this region and suggest the structure may be around $7 \mathrm{~km}$ long.

\section{Ivan River}

The Ivan River gas field was discovered in 1966 and, according to a structure contour map provided by the field operator for the AOGCC annual summary, the structure is about $7.5 \mathrm{~km}$ long (feature 11, figs. 1, 3). The wells in the field are flanked by moderate-intensity aeromagnetic highs, which trend north-northeast, parallel to the flanks of the fold. We infer that the structure extends for the length of the flanking aeromagnetic anomalies. To the north, the East Lewis River No. 1 well lies along the same trend, and we infer it is positioned on the same fold (fig. 1).

\section{Lewis River-Pretty Creek}

The Lewis River gas field was discovered in 1975 and occupies a north-south trending anticline (feature 12, figs. 1, 3 ). According to a structure contour map provided by the field operator for the AOGCC annual summary, the structure is about $6.7 \mathrm{~km}$ long. High-frequency aeromagnetic anomalies, which flank producing wells along the structure, indicate the Lewis River fold is roughly $6 \mathrm{~km}$ longer and extends southsouthwestward. The southern end of this structure, and the flanking aeromagnetic anomalies, connect with the Pretty Creek field. A lack of wells between the two fields suggests there is a saddle between the fields. This structure also is along the trend of the Beluga River field, which suggests the master faults coring the structures are connected at depth.

\section{Beluga River}

The Beluga River gas field was discovered in 1962 and, according to a structure contour map provided to the AOGCC by the field operator, the structure is about $12 \mathrm{~km}$ long (feature 13, figs. 1, 3). We extend the structure to the south based on the trend of prominent flanking magnetic anomalies originating from magnetic strata probably in the upper part of the Sterling Formation (Saltus and others, 2001). A seismicreflection profile across the fold indicates it is a fault-cored fold and that growth strata were deposited along its northwest side (Haeussler and others, 2000).

\section{North Cook Inlet-SRS}

The North Cook Inlet structure and the SRS structure have previously have been considered separately, but the aeromagnetic data indicate they constitute one structure (feature 14, figs. 1, 3). The northern North Cook Inlet gas field was discovered in 1962. A seismic-reflection profile across the northern part of the structure shows that it is a fault-cored fold (Haeussler and others, 2000). North-northeast trending high-frequency aeromagnetic anomalies flank the fold axis. These anomalies nearly converge to the north-northeast of the structure, which suggests that the fold plunges to the north. To the south-southwest of the North Cook Inlet structure, the magnetic anomalies also flank the SRS fold. Therefore, the magnetic data indicate the SRS and the North Cook Inlet folds constitute one longer fold. The anomalies constrict slightly between the two named folds where the North Cook Inlet and SRS fields lie, which suggests that there is a structurally lower saddle between two highs. No producing oil or gas wells lie between the two fields, therefore, the fields likely are anticlinal crests with a saddle in between.

\section{Moquawkie}

The Moquawkie field was discovered in 1965 (feature 15, figs. 1, 3). No structure contour maps of the field 
were provided to the AOGCC. We infer an anticline with a north-northeasterly trend based on regional trends of folds and the presence of an anticline along the Chuitna River (Magoon and others, 1976). Aurora Gas geologists report that the Moquawkie structure is about $12 \mathrm{~km}$ long, is westward vergent, and is a single structure with three anticlinal culminations - the Moquawkie field, the Lone Creek structure to the north, and the Kaloa structure to the south. There is no clear signature of the structure on the aeromagnetic data, and we have no seismic-reflection profile that crosses it.

\section{Nicolai Creek}

The Nicolai Creek gas field was discovered in 1966 (feature 16, figs. 1, 3). No structure contour maps of the field were provided to the AOGCC. We infer there is an anticline with a north-northeasterly trend based on the trend of nearby structures and on the presence of wildcat wells to the south of the field, which also define its length. This structure lacks an aeromagnetic signature.

\section{Granite Point}

The Granite Point oil field was discovered in 1965 and is defined clearly by the location of wells along the crest of the anticline (feature 17, figs. 1, 3). According to a structure contour map provided to the AOGCC by the field operator, the fold is about $10 \mathrm{~km}$ long. However, we infer the structure is about $5 \mathrm{~km}$ longer based on dry holes along strike, which we infer were drilled on the same structure. Because the Granite Point and Middle Ground Shoal fields are along the same trend, they may be connected at depth. The structure is poorly imaged on aeromagnetic maps. The Albert Kaloa gas field, discovered in 1968, consisted of one abandoned well without production. It is located to the northwest of the Granite Point field. We suggest the gas shows found in this well are related to the Granite Point fold, and that it is a continuous structure. Fold crests in this part of the inlet typically are 3.5-6 km apart. If there is a separate anticline at the Kaloa field, the fold crests would be only $2 \mathrm{~km}$ apart. Moreover, west-dipping Quaternary(?) beds in the vicinity of the field also do not indicate there is a separate structure (Haeussler and others, 2000).

\section{North Trading Bay}

The North Trading Bay oil field is an outlier of the Trading Bay oil field (feature 19) and, according to a structure contour map provided to the AOGCC by the field operator, the structure is oriented north-south and is about $3-\mathrm{km}$ long (feature 18, figs. 1, 3). The distribution of wells suggests that the North Trading Bay fold is a distinct structure from, and en echelon with, the Trading Bay fold. The structure is absent on the aeromagnetic maps.

\section{Trading Bay Unit—McArthur River Field}

The Trading Bay Unit or McArthur River field was discovered in 1965, and it has wells scattered over the broad crest of the anticline (feature 19, figs. 1, 3). This anticline has the largest area of fold closure of any in Cook Inlet. According to a structure contour map provided by the field operator to the AOGCC, the structure has a triangular shape and lies between faults on both its northwestern and southeastern flanks. We mapped these faults on figure 1 as shown in the AOGCC Annual Report. The structure continues to the southwest because it is imaged on a seismic-reflection profile, and because there is a southwestward linear distribution of wells. The structure is not observed on the aeromagnetic data.

\section{West McArthur River}

The north end of this fold is indicated by the linear trend of nine wells drilled along it (feature 20, figs. 1, 3). The structure is absent on the high-frequency filtered aeromagnetic data. However, numerous strong northwest-trending anomalies in this area probably obscure the signal from a small structure the size of the West McArthur River. To the south of the trend of the wells, we image a fold on a seismic-reflection profile to the south of West Foreland, which indicates the fold extends more than $9 \mathrm{~km}$ to the south. Along strike to the north of this fold lies the Trading Bay structure, which may indicate the two folds are related. However, the lack of wells drilled between the two structures, and the southward curve of the southernmost wells in the Trading Bay field indicate these probably are separate structures.

\section{McArthur River-Redoubt Shoal}

The McArthur River field was discovered in 1965 and is perhaps one of the widest in Cook Inlet, with producing wells distributed over an area $4 \mathrm{~km}$ wide (feature 21, figs. 1, 3). It is also one of the longer structures. According to a structure contour map provided to the AOGCC by the field operator, the fold is about $18 \mathrm{~km}$ long. The Redoubt Shoal structure lies along trend to the south. A structure contour map of the field provided to the AOGCC by the field operator shows a north-northeast trending structure. However, we do not place much confidence in the map because the fold trend is based on alignment of only three wells, and the contour pattern is unlike any other structure in the inlet. The high-frequency filtered aeromagnetic data indicate a well-defined linear anomaly to the east of the field, along the west side of the Middle Ground Shoal structure. A seismic-reflection profile across the south end of the Redoubt Shoal anticline is along strike from McArthur River field location to the north. Therefore, it appears the McArthur River fold and the Redoubt Shoal fold are part of the same long structure. However, because producing wells are spread over a much wider area at the north end of the feature, it suggests there may be significant structural changes between the north and south ends. 


\section{Middle Ground Shoal}

The Middle Ground Shoal oil field was discovered in 1962 and is probably the largest, tightest fold in Cook Inlet (Boss and others, 1976; Bishop, 1982) (feature 22, figs. 1, 3). It has an unusual geometry in that it is a west-vergent faultcored fold above a west-dipping master fault (see Haeussler and others, 2000). Beds in the west limb of the fold are reported by Bishop (1982) to be vertical. Wells are distributed along a $25 \mathrm{~km}$ length, but the fold is observed on a seismicreflection profile $6 \mathrm{~km}$ to the south of the southernmost wells and, thus, extends further south. A low-amplitude fold with flanking east- and west-vergent faults is located along a seismic profile $20 \mathrm{~km}$ south of the southernmost wells, which indicates the structure continues further south, and the tightness of the fold decreases dramatically south of the region with oil production. Flanking high-frequency aeromagnetic anomalies also indicate the structure extends south of the producing wells.

\section{Beaver Creek}

The Beaver Creek gas field was discovered in 1967 and, according to a structure contour map provided to the AOGCC by the field operator, the structure is about $7 \mathrm{~km}$ long (feature 23, figs. 1, 3). However, on a map of high-frequency filtered aeromagnetic data a pair of prominent $\sim 60-\mathrm{km}-$ long northeast-trending anomalies lie $8 \mathrm{~km}$ west of the field. Proprietary seismic-reflection data show that these anomalies originate from west-dipping strata in the Sterling Formation or overlying Quaternary sediments along the west flank of the Beaver Creek fold. Proprietary seismic-reflection data show the fold has a higher amplitude in the vicinity of the Beaver Creek field, and it decreases in amplitude to the north, where fold closure ceases. The seismic-reflection data show that the fold extends at least as far north as the middle of the Swanson River field. Based on the extent of the aeromagnetic anomalies, we infer it extends a few kilometers farther. The syncline between the Beaver Creek fold and the southern extension of the Swanson River fold is tight in contrast to the broader anticline crests. Thus, the Beaver Creek fold appears to be a parasitic fold on the larger Swanson River structure.

\section{Swanson River}

In 1957 the Swanson River oil field was the first oil discovery in the Cook Inlet region (feature 24, figs. 1, 3). The location and extent of the field is defined by numerous wells along the crest of the structure. A structure contour map provided by the operator to the AOGCC indicates there is at least a 15-km-long length of fold closure; and flanking aeromagnetic anomalies, which likely originate from magnetic strata in the Sterling Formation, suggest it has a much longer extent. On this basis, we infer the structure extends about $16 \mathrm{~km}$ further north. The Birch Hill gas field is part of the same structure. The magnetic anomaly on the east side of the structure is nearly $100 \mathrm{~km}$ long (see Kenai Lowlands structure). The Swanson River fold likely extends $\sim 9 \mathrm{~km}$ further south and includes the Wolf Lake field. There is a broad anticlinal culmination on an east-west seismic-reflection profile through the Beaver Creek structure. The Sterling Gas field (feature 30 ) is along strike $12 \mathrm{~km}$ to the south, and it may be part of the same structure, but without supporting evidence, we leave these as two separate structures.

\section{Kenai Lowlands}

We infer the presence of the Kenai lowlands structure from aeromagnetic data, and it may reflect the deeper structure of the lowlands (feature 25, figs. 1, 3). High-frequency filtered aeromagnetic data show several very long linear features in the Kenai lowlands (fig. 3). Two features are located between Kenai and Nikiski, and two others lie along the west side of the Swanson River fold. From examination of proprietary seismic-reflection data, we conclude that the Kenai-Nikiski aeromagnetic anomalies arise from west-dipping magnetic strata within the Sterling Formation. We have not examined seismic-reflection data across the magnetic anomaly on the east side of Swanson River, but we infer it also is related to tilted strata. The long length of the anomalies and the structural position of the feature suggest it may be similar to the Kalgin Island South structure (feature 35), which is imaged on seismic-reflection profiles as homoclinally dipping strata. Because the Swanson River fold is flanked by these anomalies, we infer that the anomaly on the east side of Swanson River is related to west-dipping strata. If this interpretation is correct, then there is a structure as long as these flanking anomalies. The lack of a mirror image of the anomalies indicates the structure is a monocline. If so, this broad flexure is narrow to the north, where the tighter fold of the Swanson River field is located, and it is diffuse with multiple folds on the limb to the south, where the Beaver Creek (23), West Fork (29), Sterling (30), and Kenai-Cannery Loop (31) folds lie. Without seismic-reflection data we are unable to further evaluate this hypothesis.

\section{Turnagain Arm}

The presence of a structure near the mouth of Turnagain Arm is enigmatic (feature 26, figs. 1, 3). Hartman and others (1972) mapped west-side-down faults in this region based on correlations of units between oil and gas wells (see Border Ranges fault discussion). The Turnagain Arm Unit No. 1 wildcat well at the entrance to Turnagain Arm indicates that at least one oil industry geologist thought there was a structure here. On a poor-quality seismic reflection line that runs from Turnagain Arm to the west-northwest, the Tertiary sediments are imaged on the top of the seismic basement. The top of the basement and the sediments thin onto the area where the wildcat well was located. We show an inferred anticline on our map, but remain unconvinced as to the presence or nature of the structure at this location. 


\section{Pincher Creek}

There is less evidence for the Pincher Creek structure than any other in Cook Inlet. It was shown on the map of Magoon and others (1976) (feature 27, figs. 1, 3). No exploratory wells have been drilled on the feature. A strong aeromagnetic anomaly lies beneath its inferred location, but it likely reflects the margin of Jurassic intrusive rocks along the Border Ranges fault (Saltus and others, 2001).

\section{Swan Lake}

The Swan Lake structure was mapped by Magoon and others (1976), and we infer its presence was deduced from a dry wildcat well (feature 28, figs. 1, 3). There is a strong aeromagnetic anomaly beneath its inferred location, which likely reflects the margin of Jurassic intrusives and the Border Ranges fault (Saltus and others, 2001).

\section{West Fork}

The West Fork gas field was discovered in 1960 (feature 29 , figs. 1, 3). No structure-contour map was provided to the AOGCC by the operator. We infer the field has a northnortheast trend based on the distribution of the discovery well and several other wildcat wells, and the regional trend of the adjacent Kenai Lowlands aeromagnetic anomaly.

\section{Sterling}

The Sterling gas field was discovered in 1961 and has two closely spaced wells (feature 30, figs. 1, 3). According to a structure-contour map provided to the AOGCC by the operator, the fold has a north-northwest trend. We infer the fold has a north-northeast trend similar to all the better documented folds nearby, as well as the trend of the Kenai Lowlands (feature 25) magnetic anomaly. There is a weak flanking aeromagnetic anomaly about $10 \mathrm{~km}$ long, which we infer is the length of the structure.

\section{Kenai-Cannery Loop}

The Kenai gas field was discovered in 1959 and, according to a structure contour map provided to the AOGCC by the operator, the field trends north-south (feature 31, figs. $1,3)$. The Cannery Loop field is $3 \mathrm{~km}$ along strike to the north and, based on the trend of the long aeromagnetic anomalies on the west side of the structure, it trends north-northeasterly. Proprietary seismic-reflection data indicate the structure fails to extend as far north as the Beaver Creek field (feature 23).

\section{Kasilof}

The Kasilof fold was mapped by Magoon and others (1976) as part of a longer structure, which we divide, on the basis of the aeromagnetic signature, into the Kasilof (feature 32, figs. 1, 3) and the Falls Creek-Ninilchik (feature 33) structures. The fold is inferred from evidence from several wildcat wells. A high-frequency aeromagnetic anomaly west of the wells trends north-south, as does the nearby Kenai field, and thus we infer this fold also trends north-south for approximately the length of the magnetic anomaly. We are unable to connect the Kasilof fold with the Falls Creek-Ninilchik fold based on the inferred north-south trend of the fold, and because the northeast end of the Falls Creek-Ninilchik fold is well defined by well locations and aeromagnetic data. Furthermore, the fold axis lies east of the trend of the Kasilof fold.

\section{Falls Creek-Ninilchik}

The Falls Creek-Ninilchik fold was mapped by Magoon and others (1976) as part of a larger structure, which we divide into the Falls Creek-Ninilchik (feature 33, figs. 1, 3) and Kasilof (feature 32) structures. The fold can be inferred from wells drilled along its length, and Buthman and Smith (2002) used seismic and gravity data to map the feature. It also is imaged clearly on the high-frequency filtered aeromagnetic data. Anomalies flank the length of the fold and define its extent. The aeromagnetic data fails to show that the fold connects with the Kasilof structure, as previously mapped. Buthman and Smith (2002) also mapped and identified on seismic-reflection profiles four normal cross faults along the shoreline of Cook Inlet. The Alaska Department of Oil and Gas (DOG) divides this structure into three pools for their unitization scheme. As they had access to proprietary oil industry data, it seems likely that this fold has three anticlinal crests with saddles in between.

\section{Deep Creek-Happy Valley}

The Deep Creek and Happy Valley fold was first mapped by Magoon and others (1976) (feature 34, figs. 1, $3)$. Eight wells were drilled along this inferred structure. The Deep Creek field operator presumably supplied sufficient information to DOG so that the field was unitized and considered a structurally distinct field, but not structurally distinct from the Happy Valley pool. The Happy Valley pool has a limited area close to the Happy Valley wells. It is notable that the alignment of the Deep Creek wells is slightly offset from the alignment of the Happy Valley wells, which suggests there is a small stepover, or jog, in the fold between the two groups of wells. The feature is poorly imaged on the aeromagnetic maps, but northeast-trending anomalies lie to the east and north. We modify the location and extent of the structure as mapped by Magoon and others (1976) based on the drilled wells and the DOG unit and pool map.

\section{Kalgin Island South}

A structure is inferred from a prominent linear aeromagnetic anomaly south of Kalgin Island (feature 35, figs. 
$1,3)$. We infer it is a monocline where flat strata in the center of Cook Inlet are tilted southeastward at the west margin of the basin. We infer this monocline for the following reasons: (1) a proprietary seismic-reflection profile that crosses the south end of this anomaly at a low angle indicates the anomaly is related to east-dipping strata in a monocline at the west margin of the basin; (2) it is not a fold because it does not have mirror-image magnetic anomalies; (3) this magnetic anomaly is located near the basin margin, and thus, it is a logical location for tilted beds; and (4) Fisher and Magoon (1978) show a seismicreflection profile to the southwest of this magnetic feature. The profile lacks a fold in the appropriate place, but there is a southeast-dipping monocline along the northwest margin of the basin. In conclusion, the evidence points to the presence of a monocline. There could be an adjacent fault associated with the relative uplift of the northwest side of the basin.

\section{Starichkof (Cosmopolitan)}

The Starichkof fold, also referred to as the Cosmopolitan unit (feature 36, figs. 1, 3), is inferred from (1) wells drilled at the north end of the feature, (2) recent wells drilled westward into the structure from near Anchor Point, (3) flanking highfrequency aeromagnetic anomalies, and (4) seismic-reflection data (Fisher and Magoon, 1978). The DOG unitized the Cosmopolitan field at the north end of the fold. Thus, the DOG must have been presented with evidence for an anticlinal crest in the area near the exploratory wells. Nonetheless, the aeromagnetic anomalies and seismic data indicate it extends another $30 \mathrm{~km}$ to the southwest. Based on these data, it is one of the longer and better defined folds in lower Cook Inlet.

\section{North Fork-Nikolaevsk}

This structure was first mapped by Magoon and others (1976) probably because the Sterling Formation crops out along the crest of this knob and because several wildcat wells lie along it (feature 37, figs. 1, 3). The AOGCC lists this as a shut-in gas field. The DOG divided this field into two units (the North Fork Unit and the Nikolaevsk Unit), which indicates that oil companies could demonstrate the presence of two antiformal closures along the fold, with a saddle in between. Weak magnetic anomalies parallel the inferred structure at the southwest end and to its east. The anomalies along the east side continue northward, which indicates that the fold extends further north than previously mapped. This fold is along strike of the Kachemak fold (feature 45) to the southwest, which was observed on seismic-reflection data by Fisher and Magoon (1978).

\section{Iniskin}

This fold was mapped by Fisher and Magoon (1978) from seismic-reflection data (feature 38, figs. 1, 3). There is a prominent magnetic anomaly $4.5 \mathrm{~km}$ to the southeast on the high-frequency filtered aeromagnetic data that is parallel to the axis of the fold as inferred by Fisher and Magoon (1978). On this basis, we infer that the trend of the axis of the fold was mapped correctly by Fisher and Magoon (1978). However, northeast of Fisher and Magoon's (1978) seismic-reflection profile, three exploratory wells were drilled slightly east of the axis of the structure. This may indicate that oil industry geologists working with proprietary seismic-reflection data found the axis of the fold to lie east of the location mapped by Fisher and Magoon (1978). If we drew the fold axis between the location mapped by Fisher and Magoon (1978) and the wells, the resultant line would fail to parallel the flanking aeromagnetic anomaly. Therefore, we leave the trend and length of the fold the same as that mapped by Fisher and Magoon (1978).

\section{Chinitna Point West}

This structure was mapped by Fisher and others (2010) using seismic-reflection data (feature 39, figs. 1, 3). The mapped sigmoidal shape is unusual and is inconsistent with the structural style of the region. Evidence for the fold is absent on aeromagnetic data. It seems possible that instead of the unusual sigmoidal shape, there could be a stepover between the northeastern and southwestern parts of the fold.

\section{Chinitna Point East}

This structure was mapped by Fisher and Magoon (1978) using seismic-reflection data (feature 40, figs. 1, 3). Fisher and others (2010) map this fold as having a longer length and different orientation, which we use for our compilation. We find no evidence for the fold on aeromagnetic data.

\section{Hawk}

This structure was mapped by Fisher and Magoon (1978) using seismic-reflection data (feature 41, figs. 1, 3). Fisher and others $(2008,2010)$ map the length and shape differently. Evidence for the fold is absent on aeromagnetic data. Fisher and others (2008) show the Hawk OCS well was drilled in a syncline west of the crest of this fold. There appears to be a link between Augustine Volcano and the Hawk structure. Fisher and others (2008) noticed there was a swarm of seismicity in the area centered around the Hawk well, which started about 8 months before the 2006 eruption of Augustine Volcano. The swarm was elongate in a west-northwesterly direction, it was about $25 \mathrm{~km}$ long and about $10 \mathrm{~km}$ wide. Earthquake hypocenters were between $10-30 \mathrm{~km}$. They also noticed a correlation between seismicity in this area and an increase in seismicity at Augustine Volcano, about 25 $\mathrm{km}$ to the southwest. After the volcano erupted, seismicity in this area subsided. The volcanic swarm was oriented west-northwest, and there are earthquake focal mechanisms consistent with right-lateral slip along a west-northwest 
trending structure. The orientation of this structure is nearly perpendicular to the folds in the region, however, the swarm structure is much deeper than the structures imaged on seismic-reflection data.

\section{East of Raven}

This fold was mapped by Fisher and others (2010) (feature 42, figs. 1, 3). Fisher and Magoon (1978) mapped a fold about $2.5 \mathrm{~km}$ to the east, but its location and length are substantially different than those of the structure in the later paper. The LCI COST No. 1 well (Magoon, 1986) was drilled in a syncline to the east.

\section{West of LCI COST No. 1}

This fold was mapped by Fisher and others (2010) (feature 43, figs. 1, 3). Fisher and Magoon (1978) mapped a fold roughly on strike to the northwest, but it is absent in the later work. Evidence for the fold is absent on aeromagnetic data. The LCI COST No. 1 well (Magoon, 1986) was drilled about $1 \mathrm{~km}$ east of the north end of the structure. Presumably it was drilled in a syncline.

\section{Starichkof Southwest}

This structure was mapped by Fisher and Magoon (1978) and by Fisher and others (2010) (feature 44, figs. 1, 3) as the southern end of the Starichkof (feature 36) fold. We interpret trends in aeromagnetic anomalies as indicating this is en echelon to the Starichkof fold, although it is located along trend.

\section{Kachemak}

The southern extent of the Kachemak fold was mapped by Fisher and Magoon (1978) using seismic-reflection data, and it also is on the map by Fisher and others (2010) (feature 45 , figs. 1, 3). At its northern end, the Kachemak No. 1 well was drilled on the inferred fold crest. The fold trace follows the trend of a prominent high-frequency aeromagnetic anomaly.

\section{Seldovia Arch}

The Seldovia arch is a well-known feature in lower Cook Inlet. The arch was first mapped by Magoon and others (1976) and Fisher and Magoon (1978) (feature 46, figs. 1, 3). This broad feature is mapped using seismic-reflection data. It lacks an aeromagnetic signature. It is the only structure in lower Cook Inlet that runs nearly perpendicular to most folds and faults. Haeussler and others (2000) speculate that the Seldovia arch formed to accommodate southwestward extrusion of the forearc. Vitrinite reflectance studies indicate that maximum burial of sediments in Cook Inlet post-date development of the arch (Johnsson and others, 1993). Fission-track studies of the nearby LCI Cost Well (Murphy and Clough, 1995) indicate little uplift. Nonetheless, reflectors within the Sterling Formation on seismic-reflection profiles are truncated as they approach the arch from the northeast. Thus, the simplest way to explain both observations is that Tertiary sediments pinch out onto the arch, and there also has been some uplift on the arch in Pliocene or younger time.

\section{Augustine East}

This fold was mapped by Fisher and others (2010) using seismic-reflection data (feature 47, figs. 1, 3). It lies between the seismic lines of Fisher and Magoon (1978).

\section{Augustine Far East}

This fold was mapped by Fisher and others (2010) using seismic-reflection data (feature 48, figs. 1, 3). It lies between the seismic lines used by Fisher and Magoon (1978), and, thus, apparently was missed in the older dataset. The structural interpretation in the area of the Augustine East and Far East folds is significantly different than that of Fisher and Magoon (1978).

\section{Lower Cook Inlet Structures}

Structures numbered 49-55 (figs. 1, 3) all were mapped by Fisher and Magoon (1978) using seismic-reflection data, and also are shown on the map by Fisher and others (2010). All these structures are broad. A test well was drilled west of the Loon (structure 50) and two wells were drilled west of the Teal (structure 52). It seems odd that the exploratory wells are not on the crest of the folds as mapped by Fisher and Magoon (1978) and Fisher and others (2008, 2010). However, the seismic line (line 21) shown in Fisher and others (2008) has numerous faults and folds in the area, and apparently, only the largest were mapped. The Sukoi Bay fold (feature 55) was mapped onshore as a broad fold in West Foreland Formation (Magoon and others, 1976).

\section{Discussion}

This revised catalog of structures in Cook Inlet is useful for considering their relationship to the regional tectonic setting. The folds in the northeastern corner of the basin lie almost parallel to the basin bounding faults. The folds along the northwestern margin of the basin (north of West Foreland and south of the Susitna River) all lie at a small angle counterclockwise to the basin bounding Bruin Bay fault. Moreover, many of these folds turn more northeasterly at their northern limit. This structural geometry is consistent with the right-lateral transpressional deformation across the basin (that is, shortening with a component of right-lateral shear) 
(Haeussler and others, 2000; Bruhn and Haeussler, 2006). Although the basic structural geometry can be seen on the map by Magoon and others (1976), the new map is far more robust.

From the Kasilof field (32, fig. 1) and northward, the folds generally trend more northerly and show a much greater degree of contraction than those to the south. The Beluga River (13), Swanson River (24), North Cook Inlet-SRS (14), Granite Point (17), and Middle Ground Shoal (22) all show significant shortening across the structures, as previously documented by numerous workers (see summary in Haeussler and others, 2000). These structures contrast with those in southern Cook Inlet, south of Kalgin Island, which show only a small amount of shortening (Fisher and Magoon, 1978; Fisher and others, 2008). In addition, this region in northern Cook Inlet with relatively tight folds correlates with the Neogene depocenter of the Cook Inlet Basin, as well as a large low on an isostatic residual gravity map (fig. 5 , Shellenbaum and others, 2010; Saltus and others 2007).

Subduction of part of the Yakutat microplate (Plafker, 1987) had a profound influence on the Neogene subsidence and deformational history of the Cook Inlet Basin. To summarize, the Yakutat collision caused counter-clockwise rotation of the southern Alaska block (Lahr and Plafker, 1980), which resulted in right-transpressional deformation across upper Cook Inlet. In this paper, we infer that a shallowereastward geometry of the subducting slab resulted in an unusually hydrated and serpentinized mantle wedge with lateral variations in heat flow beneath Cook Inlet. These conditions enhanced corner flow in the mantle wedge (in the region between the subducting slab and the base of the continental crust under Cook Inlet), which caused dynamic subsidence. In the following paragraphs we discuss these factors.

The Yakutat microplate collision is resulting in counterclockwise rotation of the southern Alaska block and righttranspressional deformation in the Cook Inlet region (figs. $5 B$, 6). Deformation across interior Alaska appears to be driven by the Yakutat collision (for example, Haeussler, 2008). The Denali fault system is the longest individual structure accommodating this collision (fig. 6). It is an active rightlateral fault, and it caused the 2002 M7.9 earthquake. As a consequence of this deformation, the region south of the Denali fault is rotating counter-clockwise (Lahr and Plafker, 1980). The western edge of the rotating southern Alaska block is not well defined, but right-transpressional deformation in the Cook Inlet region is consistent in geometry and timing with the deformation being driven by the Yakutat collision (Haeussler and others, 2000; Bruhn and Haeussler, 2006; Haeussler, 2008).

The Yakutat microplate is both colliding into and subducting beneath the southern Alaska margin, a process occurring for approximately the last 20-25 Ma (Plafker, 1987) (fig. 5B). The subducting Yakutat slab likely consists of a 24-27-km-thick (Christeson and others, 2010) package of mafic rocks, which are more buoyant and likely less water-rich than typical oceanic crust (Plafker, 1987; Eberhart-Phillips and others, 2006). The Yakutat slab is contiguous with typical oceanic crust that lies to the southwest (fig. $5 B$ ). EberhartPhillips and others (2006) mapped the three-dimensional extent of the Yakutat slab with seismic tomography and analysis of $V_{p}$ and $V_{p} / V_{s}$ ratios, and they found the edge of the subducted slab lies at the northern end of the Cook Inlet Basin (fig. 5B). Evidence for the buoyancy of the Yakutat slab can be seen in the distance between the trench and the 100$\mathrm{km}$ contour of the slab, which the arc volcanoes commonly lie above (see figure 6). In southern Cook Inlet, where typical oceanic crust is being subducted, the distance between the trench and $100-\mathrm{km}$ contour is $315-350 \mathrm{~km}$, which is still large from a global perspective. North of Cook Inlet, where the Yakutat slab is being subducted, the distance is more than $500 \mathrm{~km}$. Moreover, a notable gap in modern volcanic-arc volcanism above the subducting Yakutat slab indicates the presence of unusual conditions that prevent arc volcanism.

The edge of the Yakutat slab marks the edge of a serpentinized mantle wedge beneath Cook Inlet (YSE, fig. 5). To the southwest of the Yakutat slab edge, there is a longwavelength magnetic high, and a gravity low that extends to the southwest for the length of Cook Inlet (Saltus and others, 1999, 2001.) (Southwest of Cook Inlet, there are no magnetic data). Large magnetic highs and gravity lows are typical of many continental forearc basins and likely reflect partial serpentinization of the mantle (Blakely and others, 2005). A two-dimensional forward model of the gravity and magnetic data from upper Cook Inlet indicates the longwavelength magnetic high and the gravity low are consistent with serpentinization of the upper mantle (Saltus and others, 2001; Blakely and others, 2005). In addition, a thermal model of the southern Alaska margin (Oleskevitch and others, 1999) indicates that temperatures in the upper mantle wedge are significantly cooler than the Curie temperature of magnetite. Thus, it is reasonable to infer a source for the magnetic anomaly in the upper mantle wedge at depths of 20-30 km (Saltus and others, 2001). Magnetotelluric data from this same area (Green, 2003) also show high conductivities at depth, which are consistent with serpentinization of mafic rocks, or mafic rocks with zones of high porosity. Lastly, EberhartPhillips and others (2006) found that the mantle wedge in the Cook Inlet region has relatively low $V_{p}$ and high $V_{p} / V_{s}$, which indicates fluids in the wedge. All of these data are consistent with a hydrated mantle wedge and the Cook Inlet magnetic and gravity anomalies arising from a serpentinized part of the upper mantle (for example, Saltus and others, 2001; Blakely and others, 2005).

Previously, Saltus and others (1999) termed the magnetic high beneath Cook Inlet, the "south Alaska deep magnetic high" (fig. 5C). They extended the feature to the northeast, where the long wavelength magnetic anomaly continues. Here, we argue the character and the sources of the anomalies change across the Yakutat slab edge. Northeast of the Yakutat slab edge, there is a greater medium- to high-frequency content of the south Alaska deep magnetic high. Moreover, the source of the anomaly is likely the Talkeetna batholith, which 

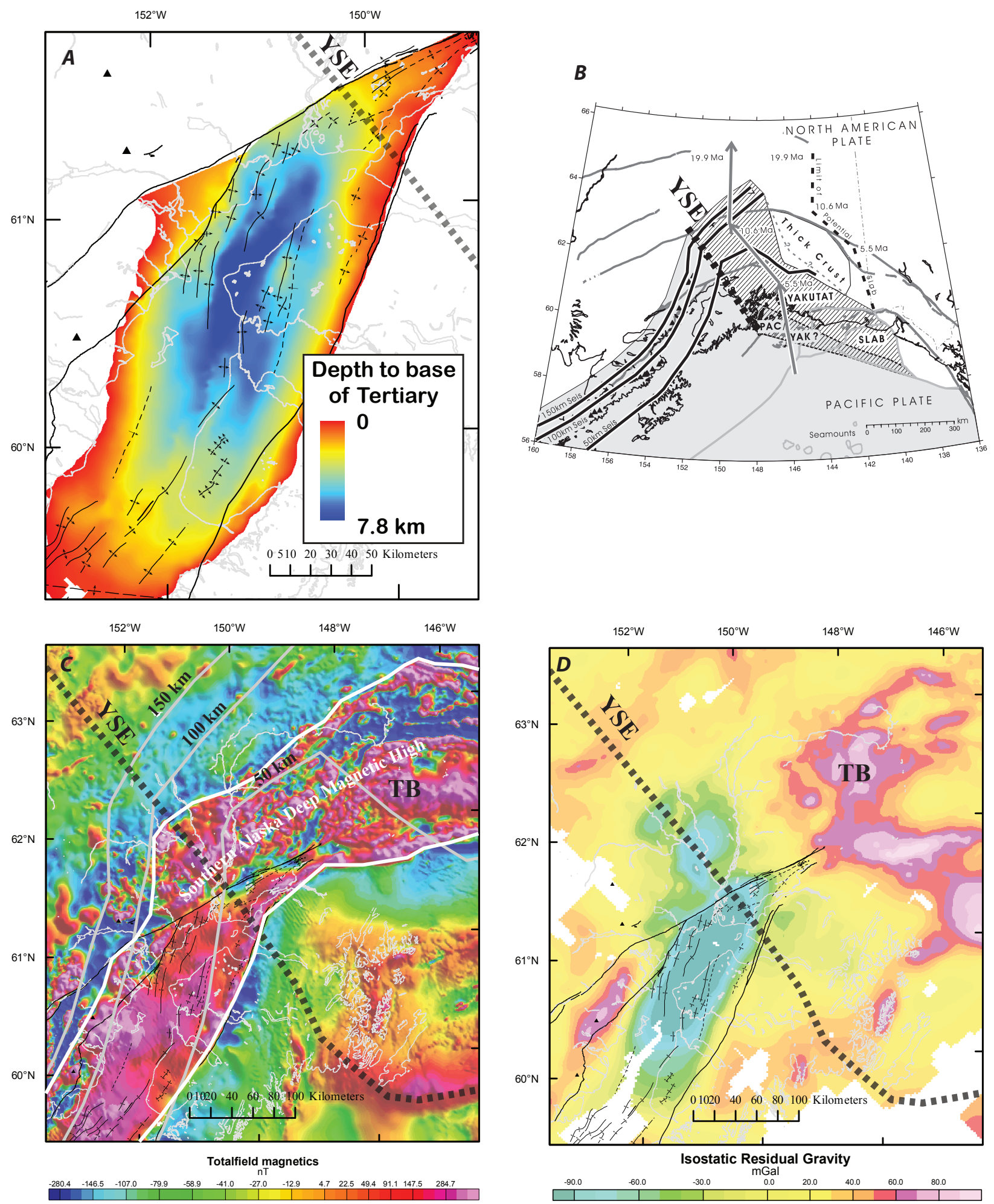

Figure 5. Maps showing the relationship of the Cook Inlet Basin to the subducted Yakutat terrane slab, Alaska. Dashed gray line is the Yakutat Slab Edge (YSE), from Eberhart-Phillips and others (2006). A, map of depth to Tertiary basement in the Cook Inlet Basin from Shellenbaum and others (2010). Symbols are those used in figure 1. B, Map showing the location of the subducting Yakutat slab from the tomography of Eberhart-Phillips and others (2006). C, Merged total field magnetic intensity map. Faults and folds are shown only for area of figure 1. Symbology is the same as figure 1. Grey contours to Benioff zone seismicity from Eberhart-Phillips and others (2006). Outline of southern Alaska Deep Magnetic High (Saltus and others, 1999) shown with white lines. TB, Talkeetna batholith. $D$, Isostatic residual gravity map. Faults and folds are shown only for the area of figure 1. Symbology is the same as figure 1. TB, Talkeetna batholith. 
consists of a vast area of Jurassic to early Tertiary intrusives (Winkler, 1992). If the south Alaska deep magnetic high was sourced entirely from the mantle wedge, it should follow the contours of the subducting slab, however, northeast of the Yakutat slab edge it does not. Instead, the south Alaska deep magnetic high crosses the 50-km contour at the Yakutat slab edge and is above a much shallower part of the slab in the Talkeetna batholith region (fig. 5C).

The serpentinized mantle wedge beneath upper Cook Inlet indicates a strongly hydrated mantle wedge, which likely had profound effects on crustal rheology. Geochemical, petrologic, and seismological observations from subduction zones around the world indicate that water in the mantle wedge can reduce the viscosity of the mantle by several orders of magnitude (Billen and Gurnis, 2001). The presence of a low $V_{p}$ and high $V_{p} / V_{s}$ mantle wedge beneath upper Cook Inlet (see figs. $6 F$ and $7 F$ in Eberhart-Phillips and others, 2006), southwest of the Yakutat slab edge, indicates the presence of fluids in the wedge. The mantle wedge above the Yakutat slab, northeast of the Yakutat slab edge, has relatively high $V_{p}$ and low $V_{p} / V_{s}$ (Eberhart-Phillips and others, 2006), indicating the absence of fluid and probably less alteration to serpentinite. Rossi and others (2006) concluded there could be up to 15 percent serpentinization in the region $<80 \mathrm{~km}$ deep where the wedge is cold. Stachnik and others (2004) examined the attenuation tomography of the mantle wedge above the Yakutat slab. They found that the wedge is highly attenuating where the slab is more than $80 \mathrm{~km}$ deep, but less attenuating

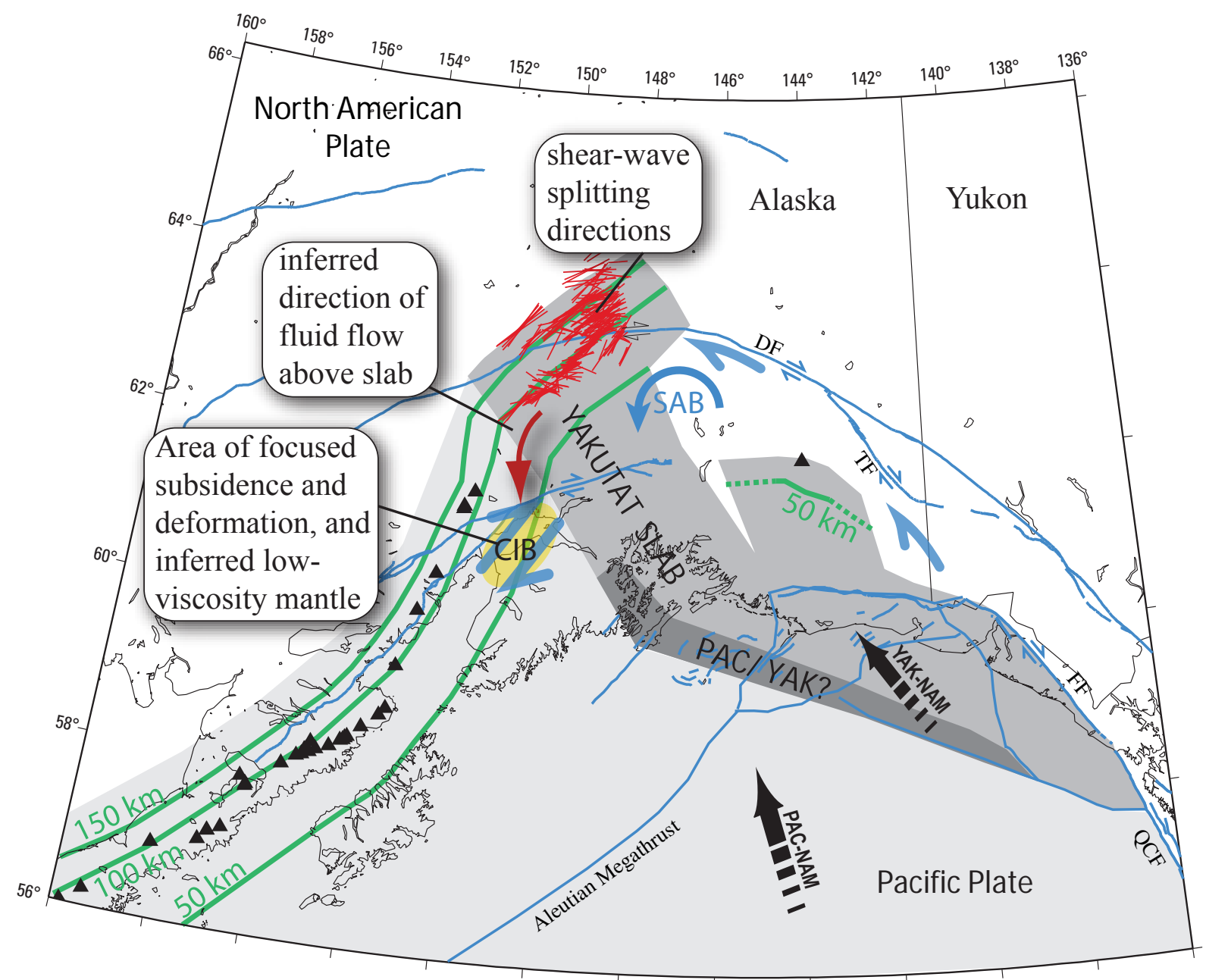

Figure 6. Map showing Yakutat slab and its inferred effect on mantle fluid flow. Figure modified from Eberhart-Phillips and others (2006). Mantle shear-wave splitting directions above subducting slab from Christensen and Abers (2010). These directions likely reflect the long axes of olivine in the mantle and are thus considered to indicate mantle flow azimuth. Contours to top of subducting slab are shown in green, active volcanoes are shown as triangles. DF, Denali fault; TF, Totschunda fault, FF, Fairweather fault; QCF, Queen Charlotte fault; SAB, southern Alaska block. 
than other wedges where less than $80 \mathrm{~km}$ deep. They argued this shallower mantle-wedge is $100-150^{\circ} \mathrm{C}$ cooler than other mantle wedges and suggested there may be less corner flow of the mantle in this region, but higher flow above the deeper part of the slab. Jadamec and Billen (2010) used a threedimensional buoyancy-driven model of the southern Alaska slab and found that mantle-flow velocity around the slab, including the region studied by Stachnik and others (2004), may be up to 10 times the driving plate velocity. There are no attenuation tomography studies to the southwest of the Yakutat slab edge, however, the $V_{p}$ and $V_{p} / V_{s}$ tomography (EberhartPhillips and others, 2006) are consistent with a wedge that has more fluids and lower viscosity. Billen and Gurnis (2001) concluded that a low-viscosity wedge has a dramatic influence on the force balance in a subduction zone and leads to an observable signal in the topography, gravity, and geoid. Such a signal is seen in Cook Inlet.

The gravity data from upper Cook Inlet are consistent with a dynamic component of basin subsidence. Topography is near sea level in the region of thick Neogene sediments in Cook Inlet Basin, and this same area also has a large, negative isostatic residual-gravity anomaly (fig. $5 D$ ). Part of this anomaly likely is due to the serpentinized upper mantle. However, the south Alaska deep magnetic high extends to southern Cook Inlet (fig. $5 C$ ), but the isostatic residual-gravity anomaly does not (fig. 5D). All of Cook Inlet lies at or near sea level, but the gravity anomaly map differs from north to south. Thus, the upper Cook Inlet region is out of isostatic balance; it is too low for the observed gravity anomaly, and the basin is being pulled downward from beneath. Lowdensity mantle material is required beneath upper Cook Inlet. To reiterate our previous inferences, this low-density mantle would be higher in fluids, lower in viscosity, and contain more serpentinite.

We speculate that the buoyant Yakutat slab acts like a squeegee to focus subducted fluids into the adjacent mantle wedge in the upper Cook Inlet region (fig. 6). Shear-wave splitting directions in the mantle above the subducting Yakutat slab (Christensen and others, 2003; Eberhart-Phillips and others, 2006; Christensen and Abers, 2010; see also the compilation in Jadamec and Billen, 2010) are oriented parallel to the strike of the slab, which suggests lateral flow away from the nose of the shallow slab. The same parallel-to-the-strikeof-the-slab flow directions were found in the recent numerical modeling work of Jadamec and Billen (2010). This flow may be like the bow wave of a blunt-nosed boat, where the water flow initially is almost perpendicular to the direction the boat is moving but later is parallel to the sides of the vessel. In the case of southern Alaska, the fluid flow would be focused away from the shallow dip region of the Yakutat slab, toward the upper Cook Inlet area, where there is a thicker mantle wedge and where oceanic slab dip is steeper. Mantle flow, although roughly parallel to the strike of the slab, also would have a downward toroidal component of corner flow in the mantle wedge to induce dynamic subsidence of the Cook Inlet Basin. As a result, there is hydration of the mantle wedge, a decrease in wedge viscosity, serpentinization, increased Neogene subsidence and deformation, and the associated isostatic residual-gravity low.

\section{Concluding Remarks}

The uncertainties in the identification and mapping of fold and fault structures combined with the imprecision in dating of movement indicate that much work remains to be done in quantifying both oil and gas potential and seismic hazards for the Cook Inlet. Aeromagnetic-data interpretation, particularly when tied to quality reflection seismic data and well control, offers great promise for mapping the full extent of many structures. Systematic collection of high-resolution seismic data with accompanying detailed bathymetry and gravity data, would greatly assist in understanding and estimating resources and hazards in Cook Inlet. Lastly, a broadband receiver function experiment, like the BEAAR study (Stachnik and others, 2004; Veenstra and others, 2006), across both sides of upper and lower Cook Inlet, would help us understand the characteristics of the mantle that drive deformation and subsidence in the region.

\section{Acknowledgments}

We thank Dwight Bradley, Ron Bruhn, Bob Swenson, and Les Magoon for thoughtful comments on the writing of the manuscript, as well as insightful technical reviews and reality checks, which resulted in a substantially improved manuscript.

\section{References}

Alaska Oil And Gas Conservation Commission, 2002, 2002 Statistical Report, accessed February 11, 2011, [http://doa. alaska.gov/ogc/annual/annindex.html].

Altstatt, A.A., Saltus, R.W., Bruhn, R.L., and Haeussler, P.J., 2002, Magnetic susceptibilities measured on rocks of the upper Cook Inlet, Alaska: USGS Open-File Report 02-0139, [http://pubs.usgs.gov/of/2002/ofr-02-0139/].

Barnes, F.F., 1966, Geology and coal resources of the BelugaYentna region, Alaska: U.S. Geological Survey Bulletin 1202-C, p. C1-C54, 4 sheets.

Barnes, F.F., and Payne, T.G., 1956, The Wishbone Hill district, Matanuska coal field, Alaska: U.S. Geological Survey Bulletin 1016, 88 p.

Billen, M.I., and Gurnis, Michael, 2001, A low viscosity wedge in subduction zones: Earth and Planetary Science Letters, v. 193, p. 227-236.

Bishop, 1982, Undrilled reserves in Cook Inlet oil fields, Alaska, in Wilson, S.T., ed., Transactions of the third Circum-Pacific energy and mineral resources conference: 
Circum-Pacific Council for Energy and Mineral Resources, v. 3., p. 117-121.

Blakely, R.J., Brocher, T.M., and Wells, R.E., 2005, Subduction-zone magnetic anomalies and implications for hydrated forearc mantle: Geology, v. 33, p. 445-448.

Boss, R.F., Lennon, R.B., and Wilson, B.W., 1976, Middle Ground Shoal oil field, Alaska: AAPG Memoir 24, p. 1-22.

Bradley, D.C., Kusky, T.M., Haeussler, P.J., Karl, S.M., and Donley, T., 1999, Geologic map of the Seldovia Quadrangle, south-central Alaska, U.S. Geological Survey Open File Report 99-18, 1 sheet, scale 1:250,000.

Bruhn, R. L., 1979, Holocene displacements measured by trenching the Castle Mountain fault near Houston, Alaska, in Short Notes on Alaskan Geology-1978: Alaska Division of Geological and Geophysical Surveys, Geologic Report 61, p. 1-13.

Bruhn, R.L., and Haeussler, P.J., 2006, Deformation driven by subduction and microplate collision - Geodynamics of Cook Inlet Basin, Alaska: Geological Society of America Bulletin, v. 118, p. 289-303.

Bruhn, R.L., Parry, W.T., and Bunds, M.P., 2000, Tectonics, fluid migration, and fluid pressure in a deformed forearc basin, Cook Inlet, Alaska: Geological Society of America Bulletin, v. 112, p. 550-563.

Bruhn, R. L., and Pavlis, T. L., 1981, Late Cenozoic deformation in the Matanuska Valley, Alaska - Three dimensional strain in a forearc region: Geological Society of America Bulletin, v. 92, p. 282-293.

Bunds, M.P., 2001, Fault strength and transpressional tectonics along the Castle Mountain strike-slip fault, southern Alaska: Geological Society of America Bulletin, v. 113, p. 908-919.

Burns, L.E., 1982, Gravity and aeromagnetic modeling of a large gabbroic body near the Border Ranges Fault, southern Alaska: U.S. Geological Survey Open-File Report 82-460, $72 \mathrm{p}$.

Buthman, D.B., and Smith, L.J., 2002, Surface expression of subsurface structure at Ninilchik Field, Kenai Peninsula, Alaska [abs.]: American Association of Petroleum Geologists Bulletin, v. 86, no. 6, p. 1139.

Calderwood, K.W., and Fackler, W.C., 1972, Proposed stratigraphic nomenclature for Kenai Group, Cook Inlet Basin, Alaska: American Association of Petroleum Geologists Bulletin, v. 56, p. 739-754.

Christensen, D.H., and Abers, G.A., 2010, Seismic anisotropy under central Alaska from SKS splitting observations: Journal of Geophysical Research, v. 115, no. B04315, doi:10.1029/2009JB006712.

Christensen, D.H., Abers, G.A., and McKnight, T.L., 2003, Mantle anisotropy beneath the Alaska range inferred from S-wave splitting observations: Results from BEAAR, Eos Transactions AGU, v. 84, no. 46, Fall Meeting Supplement, Abstract S31C-0782.

Christeson, G.L., Gulick, S.P.S., van Avendonk, H.J.A., Worthington, L.L., Reece, R.S., and Pavlis, T.L., 2010, The Yakutat terrane - dramatic change in crustal thickness across the Transition fault, Alaska: Geology, v. 38, no. 10, p.
895-898, doi:10:.1130/G31170.1

Clardy, Bruce I., 1974, Origin of the lower and middle Tertiary Wishbone and Tsadaka Formations, Matanuska Valley, Alaska: University of Alaska, Fairbanks, unpublished master's thesis, $74 \mathrm{p}$.

Dallegge, T.A., 2002, Application of 40Ar/39Ar chronostratigraphy to geologic problems in Yellowstone caldera and Cook Inlet basin: University of Alaska, Fairbanks, Ph.D. dissertation, 206 p.

Dallegge, T.A., and Layer, P.W., 2004, Revised chronostratigraphy of the Kenai Group from ${ }^{40} \mathrm{Ar} /{ }^{39} \mathrm{Ar}$ dating of low-potassium bearing minerals, Cook Inlet Basin, Alaska: Canadian Journal of Earth Sciences, v. 41, p. 11591179.

Detterman, R.L., and Hartsock, J.K., 1966, Geology of the Iniskin-Tuxedni region, Alaska: U.S. Geological Survey Professional Paper 512, 78 p.

Detterman, R.L., Hudson, T., and Hoare, J.M., 1975, Bruin Bay Fault inactive during the Holocene, in Yount, M.E., ed., U.S. Geological Survey Alaska Program, 1975: U.S. Geological Survey Circular 722, p. 45.

Detterman, R.L., Hudson, T., Plafker, G., Tysdal, R.G., Hoare, J.M., 1976b, Reconnaissance geologic map along Bruin Bay and Lake Clark Faults in Kenai and Tyonek quadrangles, Alaska: U.S. Geological Survey Open File Report 76-477, 4 p., 2 sheets, scale 1:250,000.

Detterman, R.L., Plafker, G., Hudson, T., Tysdal, R.G., and Pavoni, N., 1974, Surface geology and Holocene breaks along the Susitna segment of the Castle Mountain Fault, Alaska: U.S. Geological Survey Miscellaneous Field Studies Map MF-618, 1 sheet, scale 1:24,000.

Detterman, R.L., Plafker, G., Russell, G.T., and Hudson, T., 1976a, Features along part of the Talkeetna segment of the Castle Mountain-Caribou fault system, Alaska: U.S. Geological Survey Miscellaneous Field Studies Map MF-738, 1 sheet, scale 1:63,360.

Dickinson, W.R., and Seely, D.R., 1979, Structure and stratigraphy of forearc basins: American Association of Petroleum Geologists Bulletin, v. 63, p. 2-31.

Eberhart-Phillips, D., Christensen, D.H., Brocher, T.M., Hansen, R., Ruppert, N.A., Haeussler, P.J., and Abers, G.A., 2006, Imaging the transition from Aleutian subduction to Yakutat collision in central Alaska, with local earthquakes and active source data: Journal of Geophysical Research, v. 111, B11303, doi:10.1029/2005JB004240.

Fisher, M.A., and Magoon, L.B., 1978, Geologic framework of lower Cook Inlet, Alaska: AAPG Bulletin, v. 62, p. 373402.

Fisher, M.A., Ruppert, N.A., White, R.A., Sliter, R.W., and Wong, F.L., 2010, Distal volcano-tectonic seismicity near Augustine Volcano, in Power, J.A., Coombs, M.L., and Freymueller, J.T., eds., The 2006 eruption of Augustine Volcano, Alaska: U.S. Geological Survey Professional Paper 1769, p. 119-128 [http://pubs.usgs.gov/pp/1769].

Fisher, M.A., Sliter, R.W., and Wong, F.L., 2008, Does a boundary of the Wrangell block extend through southern 
Cook Inlet and Shelikof Strait, Alaska?, in Freymueller, J.T., Haeussler, P.J., Wesson, R.L., Ekstom, G., eds., Active tectonics and seismic potential of Alaska: AGU Monograph 179, p. 287-295.

Flores, R.M., Myers, M.D., and Striker, G.D., Houle, J.A., 1999, Core lithofacies analysis and fluvio-tidal environments in the AK 94 CBM-1 well, near Wasilla, Alaska, in Kelley, K.D., ed., Geologic studies in Alaska by the U.S. Geological Survey, 1997: U.S. Geological Survey Professional Paper 1614, p. 57-72.

Flores, R.M., and Stricker, G.D., 1993, Interfluve-channel facies models in the Miocene Beluga Formation near Homer, south Kenai Peninsula, Alaska, in, Rao, P.D., and Walsh, D.E., eds., Focus on Alaska's coal 1993: Mineral Industry Research Laboratory, University of Alaska, Fairbanks, p.140-166.

Flores, R.M., Stricker, G.D., and Roberts, S.B., 1994, Miocene coal-bearing strata of the Tyonek Formation; braidedstream deposits in the Chuit Creek-Chuitna River drainage basin, southern Alaska, in Till, A.B., and Moore, T.E. eds.; Geologic studies in Alaska by the U.S. Geological Survey, 1993: U.S. Geological Survey Bulletin 2107, p. 95-114.

Flores, R.M., Stricker, G.D., and Stiles, R.B., 1997, Tidal influence on deposition and quality of coals in the Miocene Tyonek Formation, Beluga coal field, upper Cook Inlet, Alaska, in Dumoulin, Julie A., and Gray, John E., eds, Geologic studies in Alaska by the U.S. Geological Survey, 1995: U.S. Geological Survey Professional Paper 1574, p. 137-156.

Fuchs, W.A., 1980, Tertiary tectonic history of the Castle Mountain-Caribou fault system in the Talkeetna Mountains, Alaska: University of Utah, unpublished Ph.D. dissertation, $162 \mathrm{p}$.

Gillis R.J., LePain, D.L., Ridgway, K.D., and Finzel, E.S., 2009, Reconnaissance view of an unnamed fault near Capps Glacier, northwestern Cook Inlet Basin, and its potential as a regional-scale, basin-controlling structure: Alaska Division of Geological and Geophysical Surveys Intepretive Report 2009-3, 9 p.

Grantz, A., 1966, Strike-slip faults in Alaska: U.S. Geological Survey Open-File Report 66-53, 82 p.

Green, A., 2003, Magnetotelluric crustal studies in Kenai, Alaska: Golden, Colorado, Colorado School of Mines, unpublished master's thesis, $90 \mathrm{p}$.

Haeussler, P.J., 1998, Surficial geologic map along the Castle Mountain Fault between Houston and Hatcher Pass Road, Alaska: U.S. Geological Survey Open File Report OFR 98-480, scale 1:25,000, 1 sheet [http://geopubs.wr.usgs.gov/ open-file/of98-480/].

Haeussler, P.J., 2008, An overview of the neotectonics of interior Alaska: Far-field deformation from the Yakutat microplate collision, in Freymueller, J.T., Haeussler, P.J. Wesson, R., and Ekstrom, G., eds., Active tectonics and seismic potential of Alaska: American Geophysical Union Geophysical Monograph 179, p. 83-108.

Haeussler, P.J., and Anderson, R.S., 1997, The "Twin Peaks fault"; not a tectonic or seismogenic structure, in Dumoulin, J.A., and Gray, J.E., eds., Geologic studies in Alaska by the U.S. Geological Survey, 1995: U.S. Geological Survey Professional Paper 1574, p. 93-99.

Haeussler, P.J., Best, T.C., and Waythomas, C.F., 2002, Paleoseismology at high latitudes: seismic disturbance of late Quaternary deposits along the Castle Mountain Fault near Houston, Alaska: Geological Society of America Bulletin, v. 114, p. 1296-1310, 1 plate.

Haeussler, P.J., Bruhn, R.L., and Pratt, T.L., 2000, Potential seismic hazards and tectonics of upper Cook Inlet Basin, Alaska, based on analysis of Pliocene and younger deformation: Geological Society of America Bulletin, v. 112, p. 1414-1429.

Haeussler, P.J., and Saltus, R.W., 2005, Twentysix kilometers of offset on the Lake Clark Fault since late Eocene time: in Haeussler, Peter J., and Galloway, John P., eds., Studies by the U.S. Geological Survey in Alaska, 2004: U.S. Geological Survey Professional Paper 1709-A, p. A1-A4.

Hartman, D.C., Pessel, G.H., and McGee, D.L., 1972, Kenai Group of Cook Inlet Basin, Alaska: Alaska Division of Geological and Geophysical Surveys Alaska Open File Report \#49.

Hawley, B.W., 1992, Structural, metamorphic, and geochemical study of the Seldovia Bay fault, Alaska; a relict Cretaceous subduction zone: University of Utah, unpublished master's thesis, $142 \mathrm{p}$.

Jadamec, M.A., and Billen, M.I., 2010, Reconciling surface plate motions with rapid three-dimensional mantle flow around a slab edge: Nature, v. 465, p. 338-342, doi:10.1038/ nature 09053 .

Johnsson, M.J., Howell, D.G., and Bird, K.J., 1993, Thermal maturity patterns in Alaska; implications for tectonic evolution and hydrocarbon potential: American Association of Petroleum Geologists Bulletin, v. 77, p. 1874-1903.

Kelly, T.E., 1961, Photogeology-A quick, economical tool for oil hunters: The Oil and Gas Journal, November 20, 1961, p. 265-272.

Kirschner, C.E., and Lyon, C.A., 1973, Stratigraphic and tectonic development of Cook Inlet petroleum province, in Arctic Geology: American Association of Petroleum Geologists Memoir 19, p. 396-407.

Lahr, J.C., Page, R.A., Stephens, C.D., and Fogleman, K.A., 1986, Sutton, Alaska, earthquake of 1984 - evidence for activity on the Talkeetna segment of the Castle Mountain fault system: Bulletin of the Seismological Society of America, v. 76, p. 967-983.

Lahr, J.C., and Plafker, G., 1980, Holocene Pacific-North American plate interaction in southern Alaska; implications for the Yakataga seismic gap: Geology, v. 8, p. 483-486.

Little, T.A. 1990, Kinematics of wrench and divergent-wrench deformation along a central part of the Border Ranges Fault system, northern Chugach Mountains, Alaska: Tectonics, v. 9, p. 585-611.

Little, T.A., and Naeser, C.W., 1989, Tertiary tectonics of the Border Ranges Fault system, Chugach Mountains, Alaska 
— deformation and uplift in a forearc setting: Journal of Geophysical Research v. 94, p. 4333-4359.

MacKevett, E.M., Jr., and Plafker, G., 1974, The Border Ranges fault in south-central Alaska: Journal of Research of the U.S. Geological Survey, v. 2, p. 323-329.

Magoon, L.B., 1986, ed., Geologic studies of the lower Cook Inlet COST No. 1 well, Alaska outer continental shelf: U.S. Geological Survey Bulletin 1596, 99 p.

Magoon, L.B., Adkison, W.L., and Egbert, R.M., 1976, Map showing geology, wildcat wells, Tertiary plant fossil localities, K-Ar age dates, and petroleum operations, Cook Inlet area, Alaska: U.S. Geological Survey Map I-1019.

Magoon, L.B., and Claypool, G.E.,1981, Petroleum geology of Cook Inlet basin; an exploration model, in Halbouty, M.T., ed., Energy resources of the Pacific region: American Association of Petroleum Geologists Studies in Geology, v. 12, p., 355-374.

Magoon, L.B., and Egbert, R.M., 1986, Framework geology and sandstone composition, in Magoon, Leslie B., ed., Geologic studies of the lower Cook Inlet COST No. 1 well, Alaska outer continental shelf: U.S. Geological Survey Bulletin 1596, p. 65-90.

Martin, G.C., Johnson, B.L., and Grant, U.S., 1915, Geology, and mineral resources of Kenai Peninsula, Alaska: U.S. Geological Survey Bulletin 587, 243 p., 4 sheets, scale $1: 62,500$.

Martinson, D. G., Pisias, N.G., Hays, J.D., Imbrie, J., Moore, T.C., and Shackleton, N.J., 1987, Age dating and the orbital theory of the Ice Ages - Development of a high-resolution 0 to 300,000 yr chronostratigraphy: Quaternary Research v. 27 , p. $1-29$.

Murphy, J.M., and Clough, J.G., 1995, Low-temperature thermal history of three wells in southern Alaska offshore basins - Lower Cook Inlet, Shelikof Straight and Stevenson Trough: Alaska Division of Geological and Geophysical Surveys, Public-Data File 95-23, 76 p.

Oleskevich, D.A., Hyndman, R.D., and Wang, Kelin, 1999, The updip and downdip limits to great subduction earthquakes - thermal and structural models of Cascadia, south Alaska, SW Japan, and Chile: Journal of Geophysical Research, v. 104, p. 14,965-14,991.

Parry, W.T., Bunds, M.P., Bruhn, R.L., Hall, C.M., and Murphy, J.M., 2001, Mineralogy, ${ }^{40} \mathrm{Ar} /{ }^{39} \mathrm{Ar}$ dating and apatite fission track dating of rocks along the Castle Mountain Fault, Alaska: Tectonophysics, v. 337, p. 149-172.

Pavlis, T.L., 1982, Origin and age of the Border Ranges Fault of southern Alaska and its bearing on the late Mesozoic tectonic evolution of Alaska: Tectonics, v. 1, p. 343-368.

Plafker, G., 1987, Regional geology and petroleum potential of the northern Gulf of Alaska continental margin, in Scholl, D.W., Grantz, A., and Vedder, J.G., eds., Geology and resource potential of the continental margin of western North America and adjacent ocean basins-Beaufort Sea to Baja California: Houston, Texas, Circum-Pacific Council for Energy and Mineral Resources, Earth Science Series, v. 6, p. 229-268.
Plafker, George, Detterman, R.L., and Hudson, Travis, 1975, New data on the displacement history of the Lake Clark Fault, in Yount, M.E. ed., United States Geological Survey Alaska Program, 1975: U.S. Geological Survey Circular 722, p. 44-45.

Plafker, George, Moore, J.C., and Winkler, G.R., 1994, Geology of the southern Alaska margin, in Plafker, George, and Berg, H.C., eds., The geology of Alaska: Boulder, Colo., Geological Society of America, The Geology of North America, v. G-1, p. 389-449.

Reger, R.D., and Koehler, R.D., 2009, Lake Clark fault, assessment of tectonic activity based on reconnaissance mapping of glacial deposits, northwestern Cook Inlet Alaska: EOS, Transactions American Geophysical Union, fall meeting abstract, G33B-0648.

Reinink-Smith, L.M., 1995, Tephra layers as correlation tools of Neogene coal-bearing strata from the Kenai lowland, Alaska: Geological Society of America Bulletin, v. 107, p. 340-353.

Rossi, G., Abers, G.A., Rondenay, S., and Christensen, D.H., 2006, Unusual mantle Poisson's ratio, subduction, and crustal structure in central Alaska: Journal of Geophysical Research, v. 111, no. B09311, doi:10.1029/2005JB003956.

Saltus, R.W., Hudson, T.L., and Connard, G.G., 1999, A new magnetic view of Alaska: GSA Today, v. 9, no. 3, p. 2-6.

Saltus, R.W., Haeussler, P.J., Bracken, R.E., Doucette, J.P., and Jachens, R.C., 2001, Anchorage Urban Region Aeromagnetics (AURA) project - preliminary geophysical results: U.S. Geological Survey Open-File Report 01-0085, 23 p., accessed February 17, 2011, http://geology.cr.usgs. gov/pub/open-file-reports/ofr-01-0085/].

Saltus, R.W., and Haeussler, P.J., 2004, Magnetic properties of Quaternary deposits, Kenai Peninsula, Alaska: U.S. Geological Survey Open-file report 2004-1202, accessed February 17, 2011, [http://pubs.usgs.gov/of/2004/1202/].

Saltus, R.W., Hudson, T.L., and Wilson, F.H., 2007, The geophysical character of southern Alaska-Implications for crustal evolution, in Ridgway, K.D., Trop, J.M., Glen, J.M.G., and O'Neill, J.M., eds, Tectonic growth of a collisional continental margin - Crustal evolution of southern Alaska: Geological Society of America Special Paper 431, p. 1-20, doi 10.1130/2007.2431(01).

Saltus, R.W., and Simmons, G.C., 1997, Composite and merged aeromagnetic data for Alaska - A website for distribution of gridded data and plot files: USGS Open-File Report 97-520, accessed February 17, 2011 [http://pubs. usgs.gov/of/1997/ofr-97-0520/].

Schmoll, H.R., Yehle, L.A., Gardner, C.A., and Odum, J.K., 1984, Guide to surficial geology and glacial stratigraphy in the upper Cook Inlet basin: Alaska Geological Society, Anchorage, $89 \mathrm{p}$.

Schmoll, H.R., and Yehle, L.A., 1987, Surficial geologic map of the northwestern quarter of the Tyonek A-4 quadrangle, south-central Alaska: U.S. Geological Survey Miscellaneous Field Studies Map MF-1934, scale 1:31:680. Shellenbaum, D.P, Gregersen, L.S. and Delaney, P.R., 2010, 
Top Mesozoic unconformity depth map of the Cook Inlet Basin, Alaska: Division of Geological and Geophysical Surveys Report of Investigations 2010-2, 1 sheet, scale 1:500,000.

Stachnik, J.C., Abers, G.A., and Christensen, D.H., 2004, Seismic attenuation and mantle wedge temperatures in the Alaska subduction zone: Journal of Geophysical Research, v. 109, B10304, doi:10.1029/2004JB003018.

Stamatakos, J.A., Kodama, K.P., Vittorio, L.F., and Pavlis, T.L., 1988, Paleomagnetism of Eocene plutonic rocks, Matanuska Valley, Alaska: Geology, v. 16, p. 618-622.

Swenson, R.F., 1997, Introduction to Tertiary tectonics and sedimentation in the Cook Inlet Basin, in Karl, S.M., Vaughn, N.R., and Rhyerd, T.J., eds., 1997 guide to the geology of the Kenai Peninsula, Alaska: Geological Society of Alaska, Anchorage, p. 18-27.

Turner, R.F., 1986, Paleontology and biostratigraphy of the COST No. 1 well, in Magoon, L.B., ed., Geologic studies of the lower Cook Inlet COST No. 1 well, Alaska outer continental shelf: U.S. Geological Survey Bulletin 1596, p. 29-31.

U.S. Geological Survey, 2002, Aeromagnetic surveys in the Anchorage, Iliamna, and Tyonek quadrangles, Alaska-A website for the distribution of data: U.S. Geological Survey Open-File Report 02-267, accessed February 17, 2011, [http://pubs.usgs.gov/of/2002/ofr-02-0267/].

Veenstra, E., Christensen, D.H., Abers, G.A., and Ferris, A., 2006, Crustal thickness variation in south-central Alaska: Geology, v. 34, no. 9, p. 781-784; doi: 10.1130/ G22615.1

Willis, J.B., Haeussler, P.J., Bruhn, R.L., and Willis, G.C., 2007, Holocene slip rate for the western segment of the Castle Mountain fault, Alaska: Bulletin of the Seismological Society of America, v. 97, p. 1019-1024.

Winkler, G.R., 1992, Geologic map and summary geochronology of the Anchorage $1^{\circ} \times 3^{\circ}$ quadrangle, southern Alaska: U.S. Geological Survey Map I-2283, scale: 1:250,000, 1 sheet. 
Produced in Menlo Park, California

Manuscript approved for publication, April 6, 2011

Text edited by Tracey Suzuki

Layout and design by Stephen L. Scott 


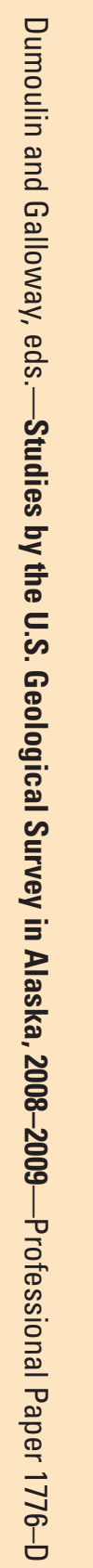

